\title{
SOEP=
}

SOEPpapers

SOEPpapers
on Multidisciplinary Panel Data Research

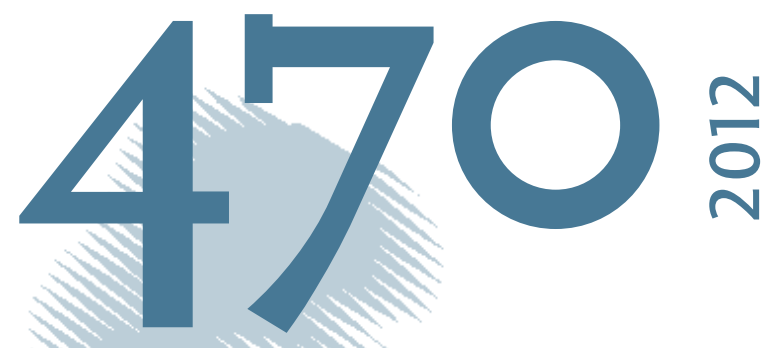

\section{Trade Union Membership and Sickness Absence: Evidence from a Sick Pay Reform}




\section{SOEPpapers on Multidisciplinary Panel Data Research}

at DIW Berlin

This series presents research findings based either directly on data from the German SocioEconomic Panel Study (SOEP) or using SOEP data as part of an internationally comparable data set (e.g. CNEF, ECHP, LIS, LWS, CHER/PACO). SOEP is a truly multidisciplinary household panel study covering a wide range of social and behavioral sciences: economics, sociology, psychology, survey methodology, econometrics and applied statistics, educational science, political science, public health, behavioral genetics, demography, geography, and sport science.

The decision to publish a submission in SOEPpapers is made by a board of editors chosen by the DIW Berlin to represent the wide range of disciplines covered by SOEP. There is no external referee process and papers are either accepted or rejected without revision. Papers appear in this series as works in progress and may also appear elsewhere. They often represent preliminary studies and are circulated to encourage discussion. Citation of such a paper should account for its provisional character. A revised version may be requested from the author directly.

Any opinions expressed in this series are those of the author(s) and not those of DIW Berlin. Research disseminated by DIW Berlin may include views on public policy issues, but the institute itself takes no institutional policy positions.

The SOEPpapers are available at

http://www.diw.de/soeppapers

\section{Editors:}

Jürgen Schupp (Sociology, Vice Dean DIW Graduate Center)

Gert G. Wagner (Social Sciences)

Conchita D'Ambrosio (Public Economics)

Denis Gerstorf (Psychology, DIW Research Professor)

Elke Holst (Gender Studies)

Frauke Kreuter (Survey Methodology, DIW Research Professor)

Martin Kroh (Political Science and Survey Methodology)

Frieder R. Lang (Psychology, DIW Research Professor)

Henning Lohmann (Sociology, DIW Research Professor)

Jörg-Peter Schräpler (Survey Methodology, DIW Research Professor)

Thomas Siedler (Empirical Economics)

C. Katharina Spieß (Empirical Economics and Educational Science)

ISSN: 1864-6689 (online)

German Socio-Economic Panel Study (SOEP)

DIW Berlin

Mohrenstrasse 58

10117 Berlin, Germany

Contact: Uta Rahmann | soeppapers@diw.de 


\title{
Trade Union Membership and Sickness Absence: Evidence from a Sick Pay Reform*
}

\author{
Laszlo Goerke \\ IAAEG - University Trier ${ }^{+}$, IZA, Bonn and CESifo, München \\ + Campus II \\ D - 54286 Trier, Germany \\ E-mail: goerke(at)iaaeg.de \\ $\&$ \\ Markus Pannenberg \\ University of Applied Sciences Bielefeld ${ }^{++}$, DIW, Berlin and IZA, Bonn \\ ++ Department of Business and Economics, Universitätsstraße 25 \\ D-33615 Bielefeld, Germany \\ E-mail: Markus.Pannenberg(at)fh-bielefeld.de
}

July 25, 2012

\begin{abstract}
In 1996, statutory sick pay was reduced for private sector workers in Germany. Using the empirical observation that trade union members are dismissed less often than non-members, we construct a model to predict how absence behaviour will respond to the sick pay reform. We show that union members may have stronger incentives to be absent and to react to the cut in sick pay. In the empirical investigation, we find a positive relationship between trade union membership and absence due to sickness and observe more pronounced reactions to the cut in sick pay among union members than among non-members. These findings suggest that more flexibility in the use of paid absence due to sickness constitutes a private gain from trade union membership.
\end{abstract}

JEL Classification: I 18, J 51, J 22

Keywords: difference-in-differences, sickness-related absence, Socio-Economic Panel (SOEP), statutory sick pay, trade union membership

* We are grateful to Nicolas Ziebarth for helpful comments and for providing background information on industry-specific bargaining contracts. Also, special thanks to Florian Baumann, Tobias Brändle, Bernd Fitzenberger, Andrey Launov, Jochen Michaelis, Patrick Puhani, Claus Schnabel, Thomas Zwick, and participants of the $15^{\text {th }}$ Colloquium on Personnel Economics in Paderborn, 74th Annual Scientific Conference of the German Academic Association for Business Research in Bolzano, the CESifo area conference on Employment and Social Protection in München, the $10^{\text {th }}$ SOEP user conference in Berlin, and seminars at CEPS/INSTEAD (Luxembourg), in Köln, Konstanz, Lüneburg, Mainz, Nürnberg, Trier and Tübingen for valuable suggestions, and to Anna Koch for excellent research assistance. Financial support from the Fritz Thyssen Stiftung is gratefully acknowledged. 


\section{Introduction}

Variations in absence rates over time and across countries suggest that absenteeism from work is not only due to sickness, but may also be a matter of choice. The evidence relating to the impact of sick pay on absences (see, e.g., Johanson and Palme 2005; Ziebarth and Karlsson 2010) provides further support for this idea. While absenteeism tends to harm firms, absent workers are likely to benefit from voluntary periods of absence. Such a conflict of interests suggests that firms will attempt to reward non-absence (e.g. Hassink and Koning 2009) and penalise absenteeism. In this case, the expected costs of absence will be lower for workers who are better protected against sanctions. Since trade unions have traditionally attempted to safeguard members from individual wage cuts, demotions or dismissals, their members face lower expected costs of absence from work. In consequence, union members are likely to be absent from work more often and for longer periods than non-members.

In this paper, we investigate the relationship between individual trade union membership and absenteeism. We focus on Germany because we can exploit a quasi-natural experiment which generates exogenous variations in sick pay and, therefore, the costs of being absent. As a first step, we develop a simple theoretical model. We assume that sanctions in the case of absence are less likely for trade union members than non-members because union membership and representation reduce the risk of dismissal (cf. Freeman 1980, Knight and Latreille 2000, and Goerke and Pannenberg 2011) and unions provide members with legal support. Membership also lowers the gain from absence, as explained below. In consequence, we derive a condition which guarantees that members will be absent for a longer period than non-members. If this condition is fulfilled, a reduction in sick pay can reduce absence by a greater amount among members than among non-members. Furthermore, a cut in sick pay has a more pronounced impact on the probability of being absent at all for union members than for non-members.

In the empirical part, we use German panel data (SOEP) and investigate the effects of a reduction in sick pay, which was lowered from $100 \%$ to $80 \%$ of foregone wages in 1996 . Since only some employees were affected by the reform, we employ a difference-indifferences (DD) approach with group-specific treatment heterogeneity to estimate the causal effect of the cut in sick pay. In particular, the regression-adjusted DD-specifications allow the treatment effect to vary between union members and non-members. We find that (1) union members were absent more often than non-members, (2) the cut in sick pay raised the proportion of members who were not absent in a given year by more than the proportion of non-members, (3) union members exhibited longer periods of absence, and (4) the cut in sick 
pay reduced the duration of absence for treated union members. Thus, our evidence provides another explanation of why workers belong to a trade union and pay membership fees, given that many of the benefits of unionism, such as higher wages, are akin to public goods in Germany. Furthermore, the study is - to our knowledge - the first to (1) use a quasi-natural experiment to determine the impact of individual union membership on absence behaviour, and (2) establish such a relationship with regard to Germany. While we cannot readily extend our findings to other countries because of institutional differences, the basic mechanism underlying our results is likely to be applicable as well.

In various contributions, sickness behaviour has been linked to the strength of trade unions. García-Serrano and Malo (2009), for example, find collective bargaining coverage at the firm level to raise involuntary (that is, mostly illness-related) absences in Spain. Chaudhury and $\mathrm{Ng}$ (1992) and Dionne and Dostie (2007) provide evidence from Canada that unionisation or bargaining coverage has a positive impact on absence. With regard to the United States, Allen (1981, 1984) and Leigh $(1981,1985)$ find a positive correlation between absence and the union status of an establishment. In addition, there are studies which focus on individual union membership. Using the University of Michigan's Quality of Employment Survey, either no correlation between individual membership and different absence indicators can be established (Leigh 1991), or a positive relationship between membership and being absent at all for blue collar workers (Leigh 1984). Vistnes (1997), using US data from the National Medical Expenditure Survey, observes membership to have a positive impact on absence among men. Looking beyond the United States, Böckerman and Ilmakunnas (2008) use the Finnish Quality of Work Life Survey and find, inter alia, that the number of illness-related absences is lower among union members than among non-members. Veliziotis (2010) bases his study on the UK Labour Force Survey and, in contrast to the results for Finland, reports positive effects of individual membership, and also of collective bargaining coverage, on the probability of being absent. Mastekaasa (2011) exploits Norwegian register data and finds a positive relationship between membership and absence. Finally, the overall effects of the sick pay reform in Germany have been documented and analysed by Ziebarth and Karlsson (2010) and Puhani and Sonderhof (2010).

The remainder of the paper is structured as follows. In Section 2, we briefly describe the institutional background in Germany, before presenting a model of absence choices in Section 3. In Section 4, we describe our data. Section 5 outlines the empirical strategy and Section 6 reports the findings. Finally, Section 7 summarises our contribution. 


\section{Institutional Background}

The key feature of the theoretical model is that union members may be absent more often, for longer periods, and react differently to a reduction in sick pay than non-members because they face lower expected costs of being absent. In particular, we propose that trade union members are dismissed less often than non-members, which is in line with empirical evidence from Germany (Goerke and Pannenberg 2011). To link this hypothesis to the institutional background, we initially describe the most important characteristics of the German industrial relations system with respect to union membership, dismissal regulations, and sick pay.

Union members pay a tax-deductible membership fee of one percent of the gross wage. In exchange, they are entitled to benefits such as strike pay, advice on job-related affairs and support in legal conflicts with the employer. In contrast to countries like the United States or the United Kingdom (Schumacher 1999, Budd and Na 2000, Eren 2009, Hildreth 2000), union members in Germany do not obtain higher wages (cf. Schmidt and Zimmermann 1991, Fitzenberger, Ernst and Haggeney 1999, and Goerke and Pannenberg 2004). ${ }^{1}$ One reason for the absence of a membership wage premium is that collective bargaining agreements effectively apply to all workers covered by such contracts and not only to union members. Hence, there is no evidence of a direct monetary gain from union membership in Germany.

Turning to dismissals, it should be noted that Germany is regarded as a country with relatively strict employment protection legislation (OECD 2004). In particular, the German Civil Code establishes notification periods for dismissals, except for cases of gross misconduct. These regulations are generally applicable, in contrast to those of the Protection Against Dismissal Act ("Kündigungsschutzgesetz", PADA), which currently basically apply only to employees who work in firms with more than ten permanent employees. The PADA establishes a restrictive set of legally admissible causes for a dismissal. One such reason is a lack of individual capabilities, including substantial absenteeism due to sickness. Furthermore, the PADA enables a worker to file a labour court suit in order to contest the termination of a contract. To obtain an idea of the importance of this option, it may be noted that about 10$15 \%$ of all dismissals appear to be challenged legally and about $20-25 \%$ of all workers who are dismissed or terminate their contract by mutual agreement obtain severance payments (cf. Pfarr et al. 2005, pp. 58, 66; Goerke and Pannenberg 2010). Importantly, from our perspective, trade unions provide dismissed members with legal advice and support them in labour court cases against their former employers. A recent survey indicates that $12 \%$ of all

\footnotetext{
${ }^{1}$ Wagner (1991) finds no effect of union membership on wages for a comprehensive sample, and a positive (negative) impact on wages when considering only blue (white) collar workers.
} 
members have been represented by their union in court and almost 50\% have obtained legal advice from union staff. ${ }^{2}$ In addition, union membership raises the likelihood that a dismissed worker will obtain severance pay (Goerke and Pannenberg 2010), and being represented by a union lawyer increases the probability of winning a labour court case (Berger and Neugart 2012). This may explain why the probability of being individually dismissed in Germany is significantly lower for union members than non-members (Goerke and Pannenberg 2011).

The features outlined above imply that the expected costs of absence from work are likely to be lower for union members. This is particularly true in Germany, where sick pay is comparatively generous. At the beginning of the 1990s, all dependent employees were legally entitled to continued wage payments for up to six weeks per sickness episode (including those resulting from workplace accidents). If the sickness lasted for more than six weeks, $80 \%$ of regular wages were replaced by the employee's (compulsory) health insurance.

On September 13, 1996, the German Parliament amended the relevant law ('Entgeltfortzahlungsgesetz'). In consequence, in the private sector sick pay relating to absences lasting up to six weeks but not due to workplace accidents, was reduced from $100 \%$ to $80 \%$ of the wage ( $\S$ 4 Sec. 1). The amendment became effective only 18 days later, on October 1, 1996, but did not apply to the public sector. ${ }^{3}$ The first proposal for an amendment of the law was apparently made in April 1996, its primary justification being to reduce labour costs. Hence, we do not need to be concerned about policy endogeneity (Puhani and Sonderhof 2010, Ziebarth and Karlsson 2010). Moreover, since basically all employees in a given firm were affected, spillover effects (cf. Hesselius, Johansson and Nilsson 2009) are no concern either. After a change in government in the second half of 1998, the cut in sick pay was revoked at the beginning of 1999. ${ }^{4}$ Additionally, the level of wage replacements for longer absences than six weeks was lowered from $80 \%$ to $70 \%$ on January $1,1997$.

While the change to the law in 1996 was clearly aimed at reducing sick payments for private sector employees, its impact varied across industries. First, trade unions filed suits at labour courts, claiming that a reference to the law in industry-specific collective agreements, which had been signed before it had changed, meant that the law's original content constituted part of the contract. Judgements relating to this issue were not uniform across bargaining

\footnotetext{
${ }^{2}$ See Einblick 08/2008 (http://einblick.dgb.de/ausgaben/einblick-ausgaben-2008; in German).

${ }^{3}$ Public sector workers were not (intended to be) affected by the reform because collective bargaining ensured a sick pay of $100 \%$. Furthermore, civil servants ('Beamte') and self-employed are not subject to this law because it relates to blue and white collar workers and apprentices only (see $\S 1$ Sec 2).

${ }^{4}$ We focus on the reduction in sick pay introduced in 1996 and do not additionally investigate the policy reversal in 1999. The main reason is that further minor changes in 1996, which also reduced the generosity of the system, were not abolished in 1999. Furthermore, the impact of overtime payments on sick pay was changed in 1999.
} 
agreements and the labour court of ultimate resort ("Bundesarbeitsgericht") published its first relevant decision in mid 1998, that is, towards the end of our observation period. Second, trade unions tried to incorporate regulations concerning sick payments into collective bargaining contracts. The content of such agreements varied across industries and did not usually re-establish the initial level of sick pay. A typical example is the construction and agriculture sector, where the cut in sick pay from $100 \%$ to $80 \%$ was implemented only for the first three days of a sickness spell. Third, trade unions had to explicitly agree to compensations, such as reduced vacation or lower bonuses, which also differed across industries. These amendments affected only about two-thirds of all employees because the remaining fraction was not covered by collective contracts in 1996 (Kohaut and Schnabel 2003). Considering these noteworthy variations in treatment intensity, the actual reform enforcement may have been related to industry-specific absence rates and hence endogenous. However, like Ziebarth and Karlsson (2010), we do not find any systematic link between industry absence rates and varying treatment intensity specified in collective agreements.

\section{Model}

In this section, we formulate a simple model which illustrates the incentives for union members and non-members to be absent from work. We focus on the length of absence periods and on their occurrence, because both measures of absenteeism are available for our empirical investigation. Additionally, we investigate whether a change in the level of sick pay affects union members and non-members differentially.

\subsection{Foundations}

There is a pool of employed workers of given size. A worker obtains a wage w (sick pay s) per day when present at (absent from) work, $0 \leq \mathrm{s} \leq \mathrm{w}$, and can select the number of days $\mathrm{d}$ $\mathrm{s} / \mathrm{he}$ is absent voluntarily in the current period. Alternatively, and without impact, sick pay could also be defined as the product of a replacement rate and the wage. Normalising working time to one and using $\hat{\mathrm{d}}$ to denote the number of days of absence due to illness that cannot be avoided, an employee's income is given by $\mathrm{w}(1-\mathrm{d}-\hat{\mathrm{d}})+\mathrm{s}(\hat{\mathrm{d}}+\mathrm{d})$, where $0 \leq \mathrm{d}, \hat{\mathrm{d}}, \mathrm{d}+\hat{\mathrm{d}}$ $\leq 1$. At the end of the period, a worker is dismissed with the probability $\mathrm{q}$, which is increasing with the duration of absence at a constant rate, $q=q(d+\hat{d}), q^{\prime}>0=q^{\prime \prime} .5$

\footnotetext{
${ }^{5}$ Note that the linearity assumption with respect to $\mathrm{q}$ is not essential. For theoretical analyses linking absence behaviour and the dismissal probability, see, for example, Allen (1981), Leigh (1985), Dionne and Dostie
} 
Workers obtain utility $\mathrm{u}$ from income and utility $\mathrm{v}$ from voluntary absence. $\mathrm{u}$ and $\mathrm{v}$ are additive and each utility function is continuous and increasing at a decreasing rate, $\mathrm{u}^{\prime}, \mathrm{v}^{\prime}>0>$ $u^{\prime \prime}, v^{\prime \prime}$. Furthermore, we assume that $\lim _{d} \rightarrow 0 v^{\prime}(d) \rightarrow \infty, v^{\prime \prime \prime}=0=v(0)$. This ensures that the marginal gain from the first unit of voluntary absence is positive. ${ }^{6}$ If a worker retains the job at the end of the period, s/he will obtain a discounted utility stream from work in the future, denoted by E. If a worker loses the job or is unemployed, future discounted utility will equal $\mathrm{U}$. We assume that retaining a job increases payoffs, so that $\mathrm{E}>\mathrm{U}$ holds, and that future utility is also additive. For simplicity and without impact on results, because q depends on $\mathrm{d}$, discounted utility streams are independent of the duration of absence in the current period.

Furthermore, we assume that being absent at all reduces expected utility by a constant amount $\mathrm{A}(\mathrm{d}+\hat{\mathrm{d}})$, where $\mathrm{A}(0)=0$ and $\mathrm{A}(\mathrm{d}+\hat{\mathrm{d}}>0):=\overline{\mathrm{A}}>0$. The parameter A could vary across workers and capture 'flat' stigma effects (Moffitt 1983) or, more broadly, represent the fixed costs of absence. Since we cannot investigate such costs empirically, we use a simple specification which guarantees that some workers choose $\mathrm{d}=0$, as is commonly observed.

Union members differ from non-members solely in two dimensions. First, they have to pay a fixed membership fee F, F $>0$. Alternatively, and more in line with the German institutional set-up, the fee $\mathrm{F}$ could also be defined as a fraction $\zeta, 0<\zeta<1$, of the wage $\mathrm{w}, \mathrm{F}=\zeta \mathrm{w}$. This modification would have no impact on results. Second, the dismissal probability of a union member $\mathrm{q}^{\mathrm{M}}$ is lower than that of a non-member $\mathrm{q}^{\mathrm{N}}$ (cf. Moreton 1998, 1999), and an extra day of absence raises the probability of losing the job by less for a member than a nonmember. Therefore, $\mathrm{q}^{\mathrm{M}}(\mathrm{d}+\hat{\mathrm{d}})<\mathrm{q}^{\mathrm{N}}(\mathrm{d}+\hat{\mathrm{d}})$ and $0<\mathrm{q}^{\mathrm{M}}(\mathrm{d}+\hat{\mathrm{d}})<\mathrm{q}^{\mathrm{N}}(\mathrm{d}+\hat{\mathrm{d}})$ hold for any given value of $d+\hat{d}$, and members and non-members will, ceteris paribus, choose different durations of absence, denoted by $\mathrm{d}^{\mathrm{M}}$ (for members) and $\mathrm{d}^{\mathrm{N}}$ (for non-members), respectively. To save on notation, we set $\hat{\mathrm{d}}=0$ and focus on voluntary absence. Moreover, employees have decided on their union status. A rationale for becoming a member in the first place can be integrated, for example, by assuming that members obtain a non-monetary benefit that varies across workers, but is uncorrelated with absence. We do not model the membership decision as our data, to be described below, does not allow us to test any resulting prediction.

(2007), and Lusinyan and Bonato (2007). Evidence for a positive impact of employment protection legislation on absence is provided by Ichino and Riphahn (2005) and Olsson (2009), inter alia.

${ }^{6}$ If, alternatively, d depicts periods of illness-related absence that could be avoided by being present at work while ill, $\mathrm{v}(\mathrm{d})$ will describe the utility gain from avoiding presenteeism. Furthermore, instead of specifying utility as $\mathrm{u}(\bullet)+\mathrm{v}(\mathrm{d})$, $\mathrm{v}$ could describe disutility from work, $\mathrm{v}=\mathrm{v}(1-\mathrm{d})$. Utility would then be $\mathrm{u}(\bullet)-\mathrm{v}(1-\mathrm{d})$. In consequence, the assumption of a marginal gain from absence can be justified on a number of grounds. 
Because of its empirical relevance (cf. Freeman 1980, Goerke and Pannenberg 2011), we will emphasise the dismissal interpretation of $q(d)$ in the theoretical set-up. Alternatively, one can understand $\mathrm{q}(\mathrm{d})$ as the probability that an individual is not promoted, that a temporary contract is not prolonged or turned into a permanent one, or that future working conditions deteriorate. Hence, the functional relationship $\mathrm{q}(\mathrm{d})$ reflects the negative impact of absence on future (expected) income, for which there is also substantial empirical evidence (see Hansen 2000, Hesselius 2007, Henningsen and Hægeland 2008, Andersen 2010, and Markussen 2012).

Collecting all of the above assumptions, expected utility $\mathrm{U}^{\mathrm{M}}$ of a union member and $\mathrm{U}^{\mathrm{N}}$ of a non-member can be expressed as follows:

$$
\begin{aligned}
& \mathrm{U}^{\mathrm{M}}\left(\mathrm{d}^{\mathrm{M}}\right)=\left(1-\mathrm{q}^{\mathrm{M}}\left(\mathrm{d}^{\mathrm{M}}\right)\right)\left\{\mathrm{u}\left(\mathrm{w}\left(1-\mathrm{d}^{\mathrm{M}}\right)+\mathrm{sd}^{\mathrm{M}}-\mathrm{F}\right)+\mathrm{v}\left(\mathrm{d}^{\mathrm{M}}\right)+\mathrm{E}\right\} \\
& +\mathrm{q}^{\mathrm{M}}\left(\mathrm{d}^{\mathrm{M}}\right)\left\{\mathrm{u}\left(\mathrm{w}\left(1-\mathrm{d}^{\mathrm{M}}\right)+\mathrm{sd}^{\mathrm{M}}-\mathrm{F}\right)+\mathrm{v}\left(\mathrm{d}^{\mathrm{M}}\right)+\mathrm{U}\right\}-\mathrm{A}\left(\mathrm{d}^{\mathrm{M}}\right) \\
& =\left\{\mathrm{u}\left(\mathrm{w}\left(1-\mathrm{d}^{\mathrm{M}}\right)+\mathrm{d}^{\mathrm{M}} \mathrm{s}-\mathrm{F}\right)+\mathrm{v}\left(\mathrm{d}^{\mathrm{M}}\right)\right\}+\mathrm{E}-\mathrm{A}\left(\mathrm{d}^{\mathrm{M}}\right)+\mathrm{q}^{\mathrm{M}}\left(\mathrm{d}^{\mathrm{M}}\right)(\mathrm{U}-\mathrm{E}) \\
& \mathrm{U}^{\mathrm{N}}\left(\mathrm{d}^{\mathrm{N}}\right)=\left\{\mathrm{u}\left(\mathrm{w}\left(1-\mathrm{d}^{\mathrm{N}}\right)+\mathrm{sd}^{\mathrm{N}}\right)+\mathrm{v}\left(\mathrm{d}^{\mathrm{N}}\right)\right\}+\mathrm{E}-\mathrm{A}\left(\mathrm{d}^{\mathrm{N}}\right)+\mathrm{q}^{\mathrm{N}}\left(\mathrm{d}^{\mathrm{N}}\right)(\mathrm{U}-\mathrm{E})
\end{aligned}
$$

The optimal durations of absence are denoted by $\mathrm{d}^{\mathrm{M}} *$ and $\mathrm{d}^{\mathrm{N} *}$ and implicitly defined by:

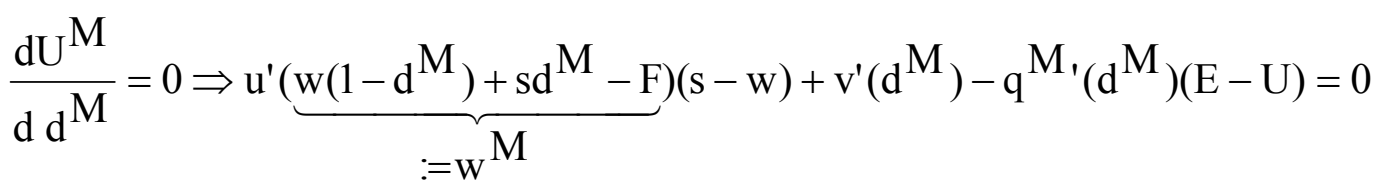

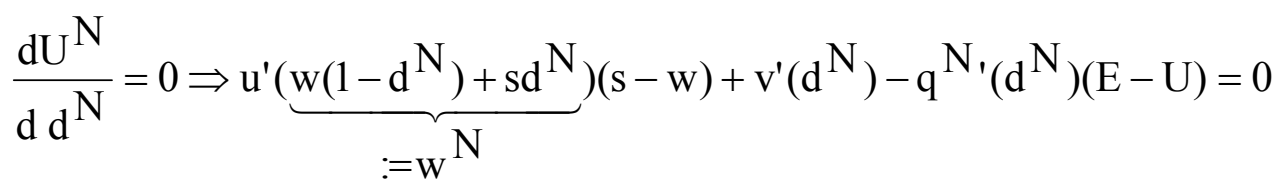

The optimal number of days of absence results from the trade-off between a gain in the form of a higher marginal utility $\mathrm{v}^{\prime}(\mathrm{d})$ from leisure, on the one hand, and the costs, on the other. These costs result from the lower marginal utility of consumption $\mathrm{u}^{\prime}(\mathrm{w})(\mathrm{s}-\mathrm{w})$, given that sick pay is less than the wage, and the rise in the dismissal probability q. Since the utility functions $\mathrm{u}$ and $\mathrm{v}$ are strictly concave, the first-order conditions define unique maxima. The model predicts, inter alia, that the optimal length of absence periods rises with sick pay $\mathrm{s}$ and the utility stream from unemployment $\mathrm{U}$, while the duration declines with the wage $\mathrm{w}^{7}$

\footnotetext{
${ }^{7}$ The prediction that sick pay raises absence can be derived in various theoretical frameworks. See, for example, Allen (1981), Brown and Sessions (1996), Engström and Holmlund (2007), and Lusinyan and Bonato (2007).
} 
A worker will be absent if the expected utility from being absent for the optimal number of days exceeds the expected utility from not missing work at all. In the case of a union member, therefore, the subsequent difference must be positive:

$$
\begin{aligned}
& U^{M}\left(d^{M}\right)-U^{M}(0)=\left\{u\left(w^{M}\left(d^{M}\right)\right)+v\left(d^{M}\right)\right\}+E+q^{M}\left(d^{M}\right)(U-E)-\bar{A} \\
&-\left[u(w-F)+E+q^{M}(0)(U-E)\right] \\
&=u\left(w^{M}\left(d^{M}\right)\right)-u(w-F)+v\left(d^{M}\right)-\left(q^{M}\left(d^{M}\right)-q^{M}(0)\right)(E-U)-\bar{A}
\end{aligned}
$$

Equation (3.5) and an analogous one for non-members suggest that absence periods are more likely, the higher sick pay s and utility from unemployment $U$ are. If the fixed costs of being absent varied across the population, those workers characterised by lower (higher) values of $\overline{\mathrm{A}}$ would constitute the fraction of workers who are (not) absent.

\subsection{Union Membership and Days of Absence}

In this sub-section we investigate whether the optimal (conditional) duration of absence varies with union membership and how a change in sick pay s alters the difference $\mathrm{d}^{\mathrm{M} *}-\mathrm{d}^{\mathrm{N}}$. In order to ascertain the relationship between $\mathrm{d}^{\mathrm{M} *}$ and $\mathrm{d}^{\mathrm{N}}$, we divide equation (3.3) by $\mathrm{q}^{\mathrm{N}}\left(\mathrm{d}^{\mathrm{N} *}\right)(\mathrm{E}-\mathrm{U})>0$, and evaluate the resulting expression at the non-members' choice, $\mathrm{d}^{\mathrm{N} *}$, implying that $\mathrm{u}^{\prime}\left(\mathrm{w}^{\mathrm{N}}\right)(\mathrm{s}-\mathrm{w})+\mathrm{v}^{\prime}\left(\mathrm{d}^{\mathrm{N} *}\right)=\mathrm{q}^{\mathrm{N}^{\prime}}\left(\mathrm{d}^{\mathrm{N} *}\right)(\mathrm{E}-\mathrm{U})$ holds. This yields:

$$
\begin{aligned}
& \left.\frac{1}{q^{N_{\prime}\left(d^{N_{*}}\right)(E-U)}}\left(\frac{d U^{M}}{d d^{M}}\right)\right|_{d^{M}=d^{N}}=
\end{aligned}
$$

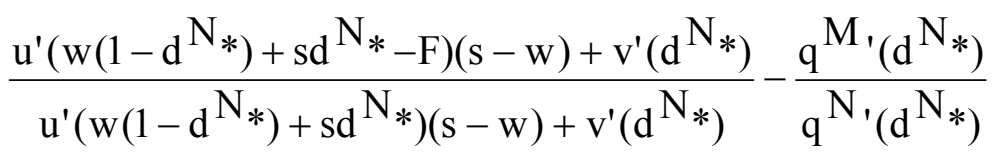

Since the membership fee $\mathrm{F}$ is positive and marginal utility $\mathrm{u}^{\prime}$ is declining in income, the numerator of the first term on the right-hand side of equation (3.6) will be smaller than the denominator if sick pay is less than the wage $(\mathrm{s}<\mathrm{w})$. Ceteris paribus, the membership fee effect induces trade union members to be absent for shorter periods than non-members. This is the case because the income reduction resulting from the fee raises marginal utility. Hence, the additional income from an extra day of work, if the wage exceeds sick pay, is valued more by a union member than a non-member. The differential dismissal effects of days of absence 
for members and non-members, captured by the second term in (3.6), imply that membership has an opposite impact on absence (since $\mathrm{q}^{\mathrm{M}^{\prime}}(\mathrm{d})<\mathrm{q}^{\mathrm{N}^{\prime}}(\mathrm{d})$ ). In sum, membership provides workers with partial insurance against the consequences of absence. The price to be paid for this insurance is the membership fee F. If the insurance impact dominates the price effect, union members will be absent for longer periods. We can, therefore, conclude the following:

\section{Proposition 1:}

If sick pay equals the wage $(\mathrm{s}=\mathrm{w})$ or, more generally, differential dismissal effects of additional days of absence are sufficiently strong, trade union members will, ceteris paribus, be absent from work for longer periods than non-members.

Next, we enquire how the difference between the optimal (conditional) duration of absence for members and non-members varies with sick pay. We assume that the wage $\mathrm{w}$ is given and comment on the (ir-) relevance of this simplification at the end of the section. For an ArrowPratt measure of absolute risk aversion $\mathrm{r}_{\mathrm{a}}(\mathrm{w}):=-\mathrm{u}^{\prime \prime}(\mathrm{w}) / \mathrm{u}^{\prime}(\mathrm{w})$, we obtain:

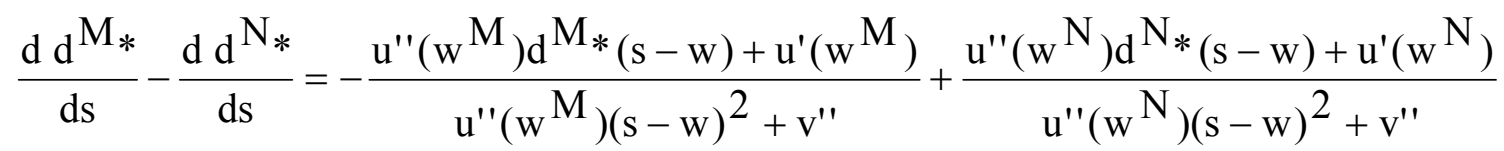

$$
\begin{aligned}
& =\frac{r_{a}\left(w^{M}\right) d^{M_{*}(w-s)+1}}{r_{a}\left(w^{M}\right)(s-w)^{2}-\frac{v^{\prime \prime}}{u^{\prime}\left(w^{M}\right)}}-\frac{r_{a}\left(w^{N}\right) d^{N_{*}}(w-s)+1}{r_{a}\left(w^{N}\right)(s-w)^{2}-\frac{v^{\prime \prime}}{u^{\prime}\left(w^{N}\right)}}
\end{aligned}
$$

As pointed out above, higher sick pay raises the duration of absence. If absolute risk aversion is constant and union members are weakly more absent than non-members $\left(\mathrm{d}^{\mathrm{M} *} \geq \mathrm{d}^{\mathrm{N} *}\right),{ }_{\mathrm{w}}^{\mathrm{M}}$ $<{ }_{\mathrm{w}} \mathrm{N}$ and $\mathrm{u}^{\prime}\left({ }_{\mathrm{w}} \mathrm{M}\right)>\mathrm{u}^{\prime}\left({ }_{\mathrm{w}}{ }^{\mathrm{N}}\right)$ will hold. In consequence, days of absence taken by union members will rise by more with an extension of sick pay than days of absence taken by nonmembers. ${ }^{8}$ If sick pay is reduced marginally from an initial level of $100 \%$, that is from $\mathrm{s}=\mathrm{w}$, then union members will unambiguously respond by reducing the (conditional) duration of absence more strongly. We may summarise our findings in

\section{Proposition 2:}

Assume that a trade union member is initially absent for a weakly greater number of days than a non-member $\left(\mathrm{d}^{\mathrm{M} *} \geq \mathrm{d}^{\mathrm{N} *}\right)$, and that either sick pay at first equals

\footnotetext{
${ }^{8}$ Imposing additional restrictions, the sign of $\mathrm{d}\left(\mathrm{d}^{\mathrm{M} *}-\mathrm{d}^{*}\right) / \mathrm{ds}$ can also be determined for an Arrow-Pratt measure of absolute risk aversion $r_{a}$ which varies with income. Furthermore, $d \mathrm{~d} M * / \mathrm{ds}>\mathrm{d} d \mathrm{~N} * / \mathrm{ds}$ will also hold if the Arrow-Pratt-measure of relative risk aversion is constant and exceeds $F /\left[(w-s)\left(d^{M} *-d^{N} *\right)\right]+1$.
} 
the wage $(\mathrm{s}=\mathrm{w})$, or that absolute risk aversion is constant. A marginal reduction in sick pay will then lower the number of days of absence by more for the union member than for the non-member.

The greater responsiveness to variations in sick pay of trade union members than of nonmembers is due to the assumption of strict risk aversion and the fact that union members have a lower income, which results from the payment of the membership fee and, for $\mathrm{s}<\mathrm{w}$, from more days of absence. In consequence, a member's marginal utility from income is higher and a decline in sick pay raises the gain from an extra day of work, relative to the situation for a non-member. The assumptions of constant absolute risk aversion or of full sick pay $(\mathrm{s}=\mathrm{w})$ ensure that the above marginal incentive is not counteracted by level effects.

If the wage $\mathrm{w}$ is not exogenous but adjusts to the fall in sick pay s, i.e. $\mathrm{w}=\mathrm{w}(\mathrm{s})$, for example, because trade unions respond in their wage setting behaviour, Proposition 2 will basically be unaffected as long as the difference between the wage and sick pay, w(s) - s, does not fall. This restriction ensures that lower sick pay reduces income at the original level of absence. In the case of constant risk aversion, $\mathrm{dw}_{\mathrm{w}} \mathrm{M} * / \mathrm{ds} \geq \mathrm{dw} \mathrm{N} * / \mathrm{ds}$ is required additionally, to guarantee that wage changes do not compensate the impact of the alteration in sick pay.

\subsection{Union Membership and the Incidence of Absence}

Propositions 1 and 2 will be applicable if the optimal duration of absence is realised. However, all those workers for whom the fixed costs of being absent at all are sufficiently high will not miss work in the first place. Therefore, we now examine whether a change in sick pay affects the willingness to be absent at all for union members and non-members differently. The member (non-member) who is indifferent between always going to work and being absent for the optimal number of days is defined by $\left.\Delta \mathrm{M}:=\mathrm{UM}_{(\mathrm{d}} \mathrm{M}^{*}\right)-\mathrm{U}^{\mathrm{M}}(0)=0$ $\left(\Delta^{\mathrm{N}}:=\mathrm{U}^{\mathrm{N}}\left(\mathrm{d}^{\mathrm{N} *}\right)-\mathrm{U}^{\mathrm{N}}(0)=0\right)$. Differentiation of $\Delta^{\mathrm{M}}$ and $\Delta^{\mathrm{N}}$ for a given wage $\mathrm{w}$ yields:

$$
\begin{gathered}
\frac{\mathrm{d} \Delta^{\mathrm{M}}}{\mathrm{ds}}=\frac{\partial \Delta^{\mathrm{M}}}{\partial \mathrm{s}}+\frac{\partial \Delta^{\mathrm{M}}}{\partial \mathrm{d}^{\mathrm{M}}} \frac{\partial \mathrm{d}^{\mathrm{M}} *}{\partial \mathrm{s}}=\frac{\partial \Delta^{\mathrm{M}}}{\partial \mathrm{s}}+\underbrace{\frac{\partial \mathrm{U}^{\mathrm{M}}}{\partial \mathrm{d}^{\mathrm{M}}}}_{=0} \frac{\partial \mathrm{d}^{\mathrm{M}}}{\partial \mathrm{s}}=\mathrm{pu}^{\prime}\left(\mathrm{w}^{\mathrm{M}}\right) \mathrm{d}^{\mathrm{M}_{*}>0} \\
\frac{\mathrm{d} \Delta^{\mathrm{N}}}{\mathrm{ds}}=\frac{\partial \Delta^{\mathrm{N}}}{\partial \mathrm{s}}=\operatorname{pu}^{\prime}\left(\mathrm{w}^{\mathrm{N}}\right) \mathrm{d}^{\mathrm{N}_{*}>0}
\end{gathered}
$$


For $\mathrm{d}^{\mathrm{M} *} \geq \mathrm{d}^{\mathrm{N} *}, \mathrm{w}^{\mathrm{M}}<\mathrm{w}^{\mathrm{N}}$ holds, and $\mathrm{u}^{\prime}\left(\mathrm{w}^{\mathrm{M}}\right)>\mathrm{u}^{\prime}\left(\mathrm{w}^{\mathrm{N}}\right)$ results. Therefore, a rise in sick pay has more pronounced effects on the expected utility from being absent (and none on the expected utility from not being absent) for members than for non-members. This generates

\section{Proposition 3:}

Assume the optimal number of days of absence to be weakly greater for a union member than for a non-member. A marginal reduction in sick pay will have a more pronounced positive impact on the probability of not being absent at all for a union member than for a non-member.

The intuition for Proposition 3 is the following. Higher sick pay makes it more likely that the utility from being (optimally) absent is sufficiently large to compensate for the fixed costs of taking at least one day off. This positive impact will be more pronounced, the greater the marginal utility from sick pay. Since union members will have a lower income than nonmembers if they are absent for at least as many days as non-members, their incentives not to be absent if sick pay is cut will be greater than the incentives for non-union workers. ${ }^{9}$

\section{Data and Variables}

Our empirical analysis is based on the German Socio-Economic Panel (SOEP), a nationally representative longitudinal data set, which started in $1984 .{ }^{10}$ Since the sick pay reform became effective on October 1, 1996 and was repealed on January 1, 1999, we extract the two postreform years, 1997 and 1998, and three pre-reform years from 1993 to 1995 from the SOEP database. Our choice rests on two reasons. First, information on absence is obtainable only for an entire calendar year and, second, it is not available for 1992. Furthermore, we focus on workers who are eligible for sick pay and the self-employed, in part-time or full-time work, and aged between 18 and 65 . We discard all observations of respondents who experienced a workplace accident in a given year since the reform in 1996 did not affect resulting payments. Furthermore, we exclude all observations with uninterrupted sickness spells of more than six weeks. Because sick pay for such long-term absence was reduced on January 1, 1997, workers exhibiting such absence periods faced a different treatment and, hence, incentive structure

\footnotetext{
${ }^{9}$ If the wage $\mathrm{w}$ changes in response to the cut in sick pay s, i.e. $\mathrm{w}=\mathrm{w}(\mathrm{s})$, Proposition 3 will continue to hold as long as the income ${ }_{\mathrm{w}} \mathrm{M} *$ of members declines with the fall in sick pay by more than the income ${ }_{\mathrm{w}} \mathrm{N} *$ of nonmembers does, that is, $\mathrm{dw}_{\mathrm{w}} \mathrm{M} * \mathrm{ds}=\mathrm{d} \mathrm{M} *+(1-\mathrm{d} \mathrm{M} *)(\mathrm{dw} / \mathrm{ds})>\mathrm{dw} \mathrm{N} * / \mathrm{ds}=\mathrm{d}^{\mathrm{N} *}+(1-\mathrm{dN} *)(\mathrm{dw} / \mathrm{ds})$ holds.

10 Haisken-DeNew and Hahn (2010) and Wagner, Frick and Schupp (2007) extensively discuss the characteristics of this panel data set. For further information, see: http://www.diw.de/english/soep/29012.html.
} 
than those characterised by shorter-term sickness absence. ${ }^{11}$ Observations with item nonresponse on relevant covariates are omitted from the regression analysis.

To the best of our knowledge, the SOEP is the only available data source in Germany that includes detailed information on absence and individual union membership for the time period of interest. More specifically, it provides a self-reported measure of the total number of working days missed due to sickness in the last calendar year. The exact wording of the question reads as follows: "How many days were you not able to work in 19XX because of illness? Please state all the days, not just those for which you had an official note from your doctor. $\{a\}$ None (b) A total of $X$ days." We use two variables in our empirical work. The first indicates whether the respondent exhibited no absence from work at all (part (a) of the SOEPquestion) and should not be seriously affected by measurement errors. In our sample, $49 \%$ of all respondents never missed a single day of work in a given year (see Table A1 in the Appendix). This number is consistent with data provided by the statutory health insurance for the end of the 1990s. The second variable measures the total number of days of absence (part (b) of the SOEP-question). On average, every respondent is unable to work for 5.7 days per year in our sample (see Table A1). The difference to the much higher numbers provided by the statutory health insurance is mainly due to the following features. The official figures often do not take into account short-term illnesses, exclude some high-income people (who miss fewer days), but include weekends and long-term illnesses (causing $40 \%$ to $50 \%$ of all days of absence). Furthermore, they are based on a disproportionately high fraction of blue collar workers. Back-of-the envelope calculations suggest that the SOEP adequately depicts the true number of days of absence from work (see also Puhani and Sonderhoff 2010). Moreover, the policy reform in 1996 is unlikely to have had an impact on potential measurement error, leading to biased estimates of its causal effects. Nonetheless, we will discuss this issue when evaluating the robustness of our findings.

Information on union membership in the SOEP is available only for the survey years 1993 and 1998. Therefore, we impute the missing values for the year 1997 (years 1994 and 1995) using the respondents' reported membership status in 1998 (1993). Estimated net union density in our effective sample is $26 \%{ }^{12}$ The vector of further covariates used in the empirical

\footnotetext{
${ }^{11}$ Evidence supporting our empirical approach is provided by Ziebarth (2012). In Section 6.4 we present parameter estimates based on a sample also including uninterrupted long-term sickness spells.

${ }^{12}$ Net union density is defined as the ratio of employed union members to employees. Hence, the self-employed are not included and the point estimate differs from the descriptive statistics reported in the tables below. Our estimate is identical to that provided by Schnabel and Wagner (2007) for the period 1992-2004 and slightly lower than the average net union density of $28 \%$ calculated by Visser (2011) for the years 1994-1998. Both of these contributions use different data sources from ours. Note that we also obtain a point estimate of net union
} 
specifications, documented in the Appendix (Table A1), consists of personal characteristics like age, educational characteristics such as a dummy variable for having completed a university degree, job characteristics like tenure, part-time work or a measure of the degree of job autonomy, the unemployment rate at the level of the respective federal state ("Bundesland"), state dummies, additional time dummies, and individual health characteristics like the self-reported health or disability status. All these covariates are determinants of sickness-related absence commonly found important in other studies.

\section{Empirical Strategy}

\subsection{Treatment and Control Group}

The core principle of our empirical strategy is to compare workers who were affected by the sick pay reform in 1996 with those who were not. Hence, private sector employees comprise our treatment group, while public sector employees and the self-employed constitute the control group. ${ }^{13}$ Furthermore, we allow for group-specific heterogeneity in treatment effects with respect to union membership.

\subsection{Regression Difference-in-Differences Models}

To assess the effect of trade union membership on sickness-related absence, we employ the following regression formulation of a linear difference-in-differences model (DD):

$$
\begin{aligned}
\mathrm{y}_{\mathrm{it}}= & \alpha+\text { postreform }_{\mathrm{t}} \beta_{1}+\text { union }_{\mathrm{it}} \beta_{2}+\text { treatment }_{\mathrm{it}} \beta_{3} \\
& +\left(\text { postreform }_{\mathrm{t}} \times \text { treatment }_{\mathrm{it}}\right) \delta+\left(\text { postreform }_{\mathrm{t}} \times \text { treatment }_{\mathrm{it}} \times \text { union }_{\mathrm{it}}\right) \tau \\
& +\mathrm{x}_{\mathrm{it}} \gamma+\varepsilon_{\mathrm{it}},
\end{aligned}
$$

where $y_{i t}$ represents either the incidence of no absence from work because of illness (part (a) of the SOEP-question) or the annual number of days of absence by individual $i$ in year $t$ (part

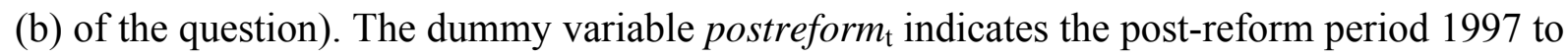
1998, union $_{\text {it }}$ describes an individual's membership status and treatment ${ }_{\text {it }}$ denotes belonging to

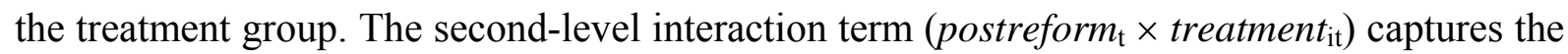

density of $26 \%$ if we do not use individual information from adjacent waves to impute the information on membership status, but instead use multiple imputation techniques.

${ }^{13}$ Note that we revise the classification of the treatment and the control group used by Ziebarth and Karlsson (2010), who erroneously stated that apprentices in the private sector were exempted from the law's change. However, labour courts repeatedly stated that this was not the case (e.g. BAG 2000) and legal scholars asserted that there was no exception for apprentices in the private sector (e.g. Bauer and Lingemann 1996). Additional robustness checks indicate that this classification issue is without empirical relevance in our sample. Moreover, in private correspondence N. Ziebarth informed us that this also holds for their sample. 
common reform effect, while the third-level interaction term (postreform $_{\mathrm{t}} \times$ treatment $_{\mathrm{it}} \times$ union $_{\mathrm{it}}$ ) is the key variable of interest. Its parameter $\tau$ measures the additional effect of being a treated union member on the particular outcome variable that goes beyond the common reform effect $\delta$. Hence, the parameter estimate reveals whether union members assigned to the treatment group responded differently to the sick pay reform than assigned non-members. Therefore, it measures the union-membership-specific intention-to-treat effect. ${ }^{14} \mathrm{x}_{\mathrm{it}}$ is the vector of covariates as described above and $\varepsilon_{\mathrm{it}}$ is the unobservable random disturbance. In particular, $\mathrm{x}_{\mathrm{it}}$ includes an indicator of the self-assessed health status and, in one robustness check, the number of days of absence in the previous year in order to take into account that absence is only partially a matter of individual choice. Parameters of equation (5.1) are estimated by OLS and their standard errors are adjusted for clustering at the personal level.

Employing DD quantile regressions, Puhani and Sonderhoff (2010) and Ziebarth and Karlsson (2010) show that the effects of the sick pay reform vary across the distribution of days of absence. We take up this finding and also analyse whether the relationship between union membership and absence varies for different points of the distribution of sickness spells. In this case, clustered standard errors come from a nonparametric panel-bootstrap procedure with 200 replications. Survey weights are used in all regression exercises. ${ }^{15}$

\subsection{Descriptive Evidence and Identification Issues}

In Figures 1 and 2, we plot the changes of the incidence of no absence and the duration of sickness-related absence for treated and non-treated union members and non-members over time for the period 1993-1998. ${ }^{16}$ Both figures clearly show that union members differ from non-members and, hence, indicate the importance of controlling for union status when analysing the determinants of absence behaviour. Union members in the control group (UM1_T0) are, for example, most likely to be on sick leave and consistently exhibit the highest average number of days of absence. In addition, treated union members (UM1_T1) are more likely to be on sick leave than non-members for the period 1993-1997 and always exhibit a higher average number of days of sickness-related absence than non-members.

\footnotetext{
${ }^{14}$ Testing for group-specific heterogeneity of treatment effects through interaction terms is prevalent in empirical work with experimental data (e.g. Hastings and Weinstein 2008). Moreover, our specification bears resemblance to difference-in-difference-in-differences specifications (DDD), where more than one control group is included (e.g. Wooldridge 2011). In DDD-specifications not only the "postreform x treatment" interaction but all secondlevel interaction terms are frequently included. We comment on the empirical relevance of incorporating further second-level interaction terms in Section 6.4.

${ }^{15} \mathrm{With}$ respect to the quantile regression, the survey weights are resampled as part of the covariate vector and used to estimate the parameters of all covariates in each replication.

${ }^{16}$ Observations for 1996 are excluded from our analysis, because the law was in effect for three months only.
} 


\section{- Figures 1 and 2 about here -}

Figures 1 and 2 also reveal that treated union members responded differently to the sick pay reform in 1996. While the share of treated union members with no sickness-related absence increased between 1997 and 1998, it decreased for the three other groups. Moreover, the average number of days of sickness-related absence declined for treated union members between 1997 and 1998 and rose for the other groups. Hence, it is important, first, to allow for union-member-specific treatment heterogeneity which, second, may vary over time.

Table 1 shows that the control and treatment groups also differ with respect to other observable characteristics. For example, union members have higher tenure, more often work in large firms and are more likely to be blue collar workers than non-members. Therefore, to account for the composition of our sample, we use regression-adjusted DD-specifications.

\section{- Table 1 about here -}

The key identifying assumption in our DD-models is that sickness leave dynamics would be the same in all four groups in the absence of treatment. Figure 1 shows that the development of the proportion of employees in the four groups with no sickness-related absence is broadly the same in the pre-reform years. Figure 2 reveals similar trends in the average number of days of absence in the pre-reform years for union members and non-members in the treatment and control groups. Hence, the figures provide supportive visual evidence for the so-called common time trend assumption. ${ }^{17}$ This is in line with the descriptive results of Ziebarth and Karlsson (2010), who compare the evolution of absence behaviour among the entire (slightly different) treatment group and control group for the same period.

When interpreting the findings for the basic DD-models, some caution may be in order because they could be affected by behavioural responses like selection out of treatment or changes in the union membership status. We explore these arguments in Section 6.4.

\section{Empirical Results}

6.1 Union Membership and the Effect of Sick Pay on the Incidence of Employee Absence Table 2 presents the results of four DD-specifications relating to the determinants of the proportion of employees with no sickness-related absence in a given year. Column 1 shows

\footnotetext{
${ }^{17}$ We also used placebo DD-specifications to indirectly test this assumption. In particular, we estimated equation (5.1) with the pseudo-reform years 1994 and 1995. For both dependent variables, namely the incidence of no absence because of illness and duration of sickness-related absence, the parameter estimates of the "placebo treatment effect" were not significantly different from zero.
} 
estimated parameters of equation (5.1) without covariates, while in Column 2 the entire set of covariates is added. Columns 3 and 4 display estimated parameters of an extended version of equation (5.1) without and with the entire set of covariates, in which we allow group-specific treatment heterogeneity to vary over the two post-reform years, 1997 and 1998. In Table 2 only estimated values for the key parameters of interest are presented, while Table A2 in the Appendix contains estimates for the entire set of covariates.

\section{- Table 2 about here -}

The estimated parameter of the triple interaction term $\left(\right.$ postreform $_{\mathrm{t}} \times$ treatment $_{\mathrm{it}} \times$ union $\left._{\mathrm{it}}\right)$, which measures union membership-specific treatment heterogeneity, is significantly positive in both specifications (Col. 1 and 2). The estimates reveal that treated union members increase their probability of not being absent at all by 6 percentage points in response to the sick pay reform, relative to treated non-members and in contrast to the control group. The point estimate implies a $12.5 \%$ change relative to the unconditional average pre-reform probability. This differential response is consistent with the results derived from the theoretical model. Moreover, in both specifications, the estimated parameter of union status is significant and indicates that membership is negatively correlated with non-absence from work, which is again in line with the predictions of our theoretical model. Combining the two parameter estimates, we find that treated union members are less likely to be absent from work after the reform than treated non-members and members of the control group.

Figure 1 suggests that the sick pay reform had effects on treated union members which varied over time. The parameter estimates presented in Columns 3 and 4 support this visual evidence. In both specifications, we find the cut in sick pay to significantly lower the probability of absence from work due to illness among treated union members for the year 1998 only. The size of the estimated parameter implies a 9 percentage point increase in the incidence of non-absence and again supports the predictions of our theoretical model. Note, moreover, that the key estimates are basically unaffected, irrespective of whether covariates are included or not. In addition, further regression analyses reveal that the effects are particularly pronounced for respondents aged between 20 and 40 years (not documented).

\subsection{Trade Union Membership and the Effect of Sick Pay on the Duration of Absence}

Table 3 contains results from linear regression DD-specifications concerning those determinants of the number of days of absence due to sickness which are of primary interest. Table A3 in the Appendix contains the full set of results. 
The estimated parameter of overall union-member-specific treatment heterogeneity is significantly negative in both specifications (Col. 1 and 2). Hence, treated union members have responded more strongly to the decline in sick pay than treated non-members, which is consistent with our theoretical model. The size of the estimated parameters indicates that treated members reduce the number of days of absence by about one. Given an average of 7.03 days in the pre-reform period, our estimates imply a fall in the duration of sicknessrelated absence by $15 \%$. As predicted by the theoretical model, union membership and the total number of days of absence are significantly and positively correlated. Once again, the strongest impact is observed for younger workers (not documented).

Estimation results for the extended version of equation (1) are presented in Columns 3 and 4 in Table 3. Only the estimated parameters for the third-level interaction term (year $1998 \times$ treatment $_{\mathrm{it}} \times$ union $_{\mathrm{it}}$ ) are significantly negative. The estimates show that treated union members have reduced their sick leave duration by roughly 1.5 days in the post-reform year 1998 , which is equivalent to a decrease of $22.5 \%$ relative to the pre-reform average.

\subsection{Union Membership and the Effect of Sick Pay Cuts across the Distribution}

Table 4 presents results from quantile regression DD-specifications for the days of absence for the 50th to 90 th quantiles since their number equals zero in the 10th to 40th quantile.

\section{- Table 4 about here -}

With respect to the overall as well as the year-specific effect in 1998, we find significantly negative parameter estimates for union-member-specific treatment heterogeneity across most parts of the upper tail of the distribution. The estimated parameters indicate that, on average, union members reduced their absence by approximately 1 to 4 days when moving up the distribution from the 50th to the 80th quantile. Comparing the estimated parameter of the overall effect for treated members with the corresponding pre-reform quantile, the percentage change shrinks from $28 \%$ for the median to $18 \%$ for the 80 th quantile. These results indicate that particularly those treated members who initially exhibit a relatively low level of sicknessrelated absence respond to the cut in sick pay and that moral hazard might play a role. Evidence provided by Ziebarth and Karlsson (2011) supports this interpretation. ${ }^{18}$

\footnotetext{
${ }^{18}$ We used a quantile regression approach to facilitate comparison with Ziebarth and Karlsson (2010). Given the problems associated with such an approach (e.g. Machado and Santos Silva 2005), we additionally estimated simple probit regressions with a dependent (dummy) variable indicating the th-quantile. Again, we find that the
} 


\subsection{Robustness Checks}

Table 5 contains estimated parameters for yearly union-member-specific treatment heterogeneity stemming from several robustness checks.

\section{- Table 5 about here -}

In a first robustness check, we considered the concern that treated (unionised) employees might have become self-employed or moved to the public sector in response to the cut in sick pay. Accordingly, we used a subsample in which only observations from respondents who did not change their job were included. The results in Column 1 of Table 5 again indicate that treated union members show a more pronounced response to the sick pay reform.

To check, second, whether changes in trade union membership status in response to the sick pay reform had any impact, we extracted a subsample of workers for whom information on membership was available both in 1993 and 1998 and membership status did not change. Column 2 of Table 5 clarifies that the results are in line with those presented above for our main specifications. Moreover, if we further restrict the sample to workers who change neither their membership nor their treatment or control group status, the estimated key parameters will be nearly identical to those reported in Tables 2 and 3 (not documented).

A key feature of our theoretical model is that the expected costs of absence are lower for union members because they are better protected against sanctions than non-members such as dismissal. This may be particularly relevant for employees subject to the Protection Against Dismissal Act (PADA). In a third robustness check we, therefore, restricted the sample to employees who work in firms with at least 20 employees (Col. 3). This is the best empirical approximation of the firm-size threshold which defines the applicability of the PADA. The results for this subsample are very similar to those reported above.

Additionally, the impact of union membership on absence due to sickness may be different in plants with a works council because of its substantial codetermination rights with respect to workplace conditions. Unfortunately, the SOEP provides no information on the existence of a works council in the period under consideration. However, we can pursue an indirect approach: The incidence of works councils increases with firm size, and in 1998 works councils existed in $86 \%$ of the firms which employed more than 200 people (Ellguth 2003). In consequence, in a fourth check we used a subsample of respondents who worked in firms with at least 200 employees (Col. 4). Again, the results were similar to those presented above.

relative effects become smaller when moving up the distribution, i.e. the absolute values of the average partial effects (APE) shrink. However, not all estimated APEs are significantly different from zero. We are grateful to Bernd Fitzenberger for bringing this methodological aspect to our attention. 
As discussed in our data section, we excluded observations with uninterrupted sickness spells greater than six weeks because such respondents faced a different incentive structure. This might confound our results since we condition on the length of the sickness spell, which is an endogenous variable. Column 5 presents results based on a sample in which we included such long-term sickness spells. Once more, the estimated parameters provide supportive evidence for the claim that union members reacted more strongly to the cut in sick pay.

Turning to Figure 1, it can be noted that, in the years 1993 to 1997, the shares of treated and non-treated union members who were never absent from work exhibited parallel trends, but that the respective share of treated members (UM1_T1) was notably larger than that of nontreated union members (UM1_T0). In contrast, there is no stable gap in levels between treated and non-treated union members in the average number of days of absence for the same years (see Figure 2). Our sixth robustness check is motivated by this observation. In consequence, we included a second-level interaction of union membership and treatment status in our extended DD-specifications (Col. 6). When doing so, the estimated parameters of this secondlevel interaction term are $0.083(\alpha=0.01)$ for the absence of any sickness spell and $-1.030(\alpha$ $=0.06$ ) for the days of absence ${ }^{19}$ The causal effect of the cut in sick pay on the incidence of absence for treated union members is similar to the previous estimates, but now imprecisely estimated ( $\alpha=0.15)$. Considering sick leave duration, the estimated causal effect of the sick pay reform for treated union members is in line with the results presented above.

Furthermore, Table 1 indicates that union members and non-members differ with respect to some covariates like tenure or blue collar worker status. It is well known in the literature (e.g. Imbens and Wooldridge 2009) that linear regression methods might react sensitively to minor changes in the empirical specification when adjusting for differences in covariates. To pursue this line of argument, we combined our extended DD-specification with (normalized) propensity score reweighting as discussed in Busso, DiNardo and McCrary (2011). The estimated propensity scores were combined with the SOEP survey weights. Column 7 shows that our main results were unaffected.

The results of five further robustness checks are summarised in the text below for convenience. The first deals with state dependence in the duration of absence. We included the lagged total number of days of sickness-related absence in our DD-specifications. The estimated parameters were around 0.3 and always highly significant. Moreover, the estimated

\footnotetext{
${ }^{19}$ From an econometric point of view, one might argue that we should additionally include the third second-level interaction ( postreform $_{\mathrm{t}} \times$ union $_{\mathrm{it}}$ ) in the empirical specification. However, in preliminary regressions the parameter estimates of this interaction were never significantly different from zero.
} 
parameters for the causal effect of the cut in sick pay for treated union members were significant at the $\alpha=0.05$ level and similar in magnitude to those presented in Section 6.2.

Because the sick pay reform became effective on October 1, 1996 and we only have yearly, retrospective information on sickness absence, we did not use observations from 1996 in our main empirical specifications. In our second further robustness check we added observations for 1996 to our sample and classified them alternatively either as pre- or as post-reform observations. The estimated parameters of key interest remained unchanged and significantly different from zero, i.e. are around $0.6(-1)$ for the incidence (duration) of sickness absence.

The remaining further robustness checks dealt with the possibility of measurement error of the endogenous variable "days of sickness-related absence for the year prior to the SOEP interview" (a), with varying treatment intensity (b), and with the heterogeneity of the control group (c). To assess whether our results are sensitive to measurement error (e.g. recall error) (a), we arbitrarily censored the dependent variable at 50, 40 or 30 days of absence. Heterogeneity of the treatment intensity occurred because, in some industries, trade unions obtained collective bargaining agreements which codified a level of sick pay of $100 \%$ (e.g. chemical industry), but had to concede on other issues (b). To tackle this issue, we pursued two strategies: First, we used a subsample without such industries in the treatment group and then employed our DD-specifications. Second, we included additional dummy variables for these industries in our DD-specifications. Finally, sanctions for being absent can be different for civil servants, white and blue collar workers in the public sector, and the self-employed. To ascertain whether the composition of the control group had an effect (c), we dropped one by one of the four above mentioned subgroups from our control group and then employed our empirical specifications with yearly union-member-specific treatment heterogeneity. In all three cases (a), (b), and (c), the estimated parameters for the causal effect of the cut in sick pay for treated union members were similar to those presented in Sections 6.2 and 6.3.

\section{Conclusions}

The starting point of our investigation is an empirical observation. Members of a trade union in Germany are less likely to be dismissed individually than non-members (cf. Goerke and Pannenberg 2011). Accordingly, the expected costs of absence may be lower for trade union members than for non-members. We set up a simple theoretical model which shows that a difference in (marginal) dismissal probabilities, or more broadly, in the likelihood of a utility reduction due to absence, may indeed induce trade union members to be absent more often 
and for longer periods than non-members. Furthermore, we establish conditions under which union members will respond more strongly to a change in the level of sick pay.

Using data from the German Socio-Economic Panel (SOEP) and difference-in-differences specifications, we find that the statutory reduction in sick pay in 1996 in Germany raised the probability of not being absent for sickness-related reasons and lowered the duration of absence periods by a greater amount for a treated member of a trade union than for a treated non-member. The estimated effects are robust and quantitatively sizeable. In particular, the cut in sick pay led to a $12.5 \%$ increase in the share of non-absent unionised employees, and on average, treated union members reduced their sick leave duration by $15 \%$ over the postreform period. In addition, the causal effect of the reform shrinks in relative terms when one moves up in the distribution of days of sickness-related absence.

Though our focus is on treatment heterogeneity with respect to union membership, we can link the evidence to the estimates provided in the literature. Ziebarth and Karlsson (2010) find that the cut in sick pay led to an increase in the share of non-absent employees of $6 \%-8 \%$ and reduced the duration of sick leave by $12 \%$. Moreover, they also observed the effect to shrink across the distribution of the sick leave duration. Puhani and Sonderhof (2010) detected a causal effect on the duration of absence of $14 \%-24 \%$, albeit imprecisely estimated in their preferred specification. Since these studies provide averages for treated members and nonmembers, the results are broadly in line with our evidence. Moreover, our results indicate substantial treatment heterogeneity and, taken at face value, suggest that the overall impact of the reform was strongly influenced by the behaviour of treated union members.

The findings of the present study are consistent with results from other countries which show that trade union membership and absence from work due to sickness are positively correlated (Leigh 1984, Vistnes 1997, Veliziotis 2010 and Mastekaasa 2011). However, we can go a step further since the reform of sick pay in Germany in 1996 allows us to causally establish the impact of individual trade union membership on absence behaviour. If union members show a more pronounced response to variations in sick pay than non-members, they will benefit more from generous sick pay. Therefore, one type of private gain from individual trade union membership may be the more extensive use of voluntary absences. Given the substantial costs of presenteeism, the disadvantages (or benefits) to society of such a private gain are an open issue. Importantly from our perspective, this private gain could help to explain why in Germany, where there is no membership wage premium, employees join trade unions. 
Figure 1: Share of Employees with no Sickness-Related Absence

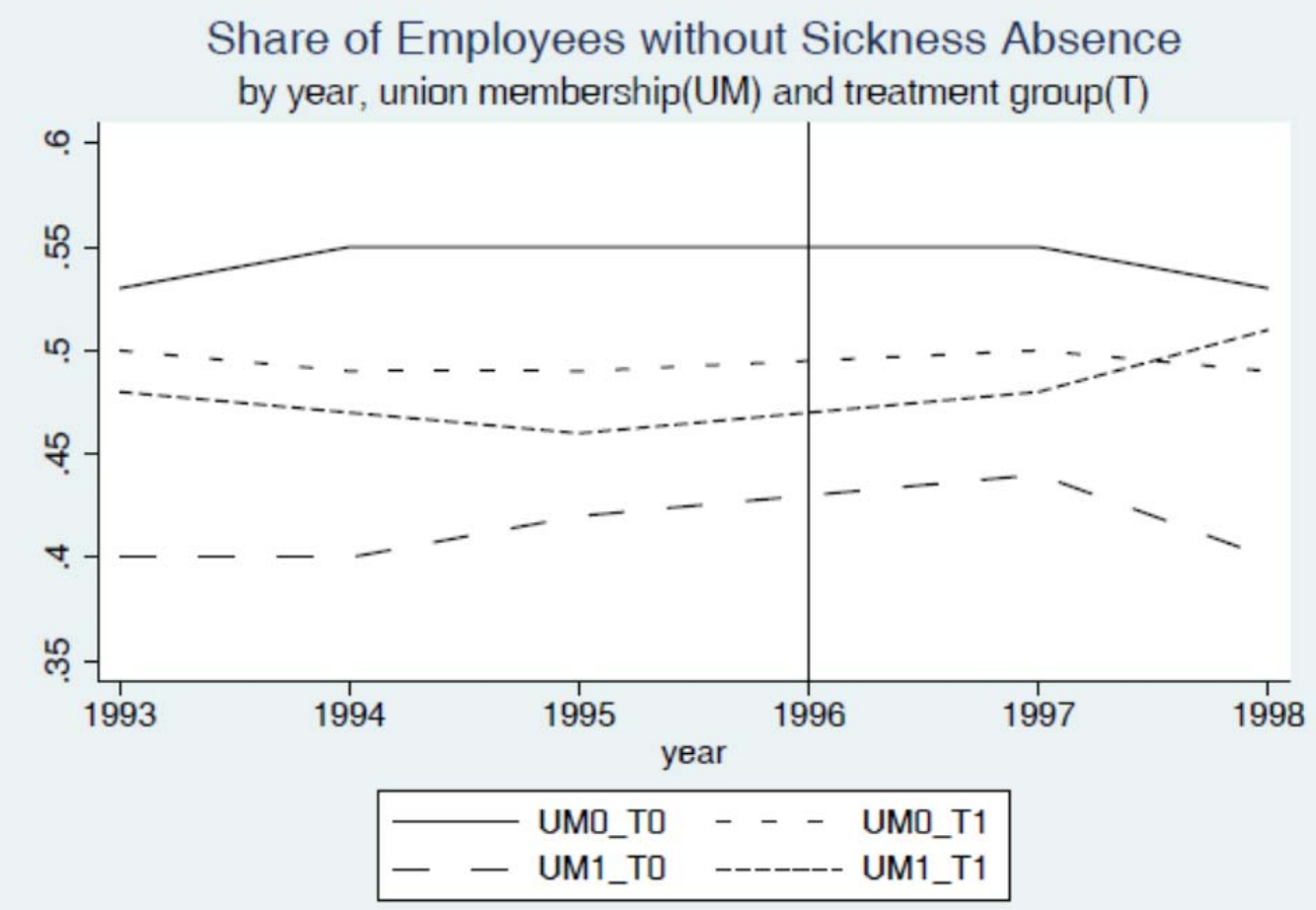

Source: SOEP: 1993-1999.

Figure 2: Average Number of Days of Sickness-Related Absence

Average Days of Sickness Absence

by year, union membership $(\mathrm{UM})$ and treatment group $(\mathrm{T})$

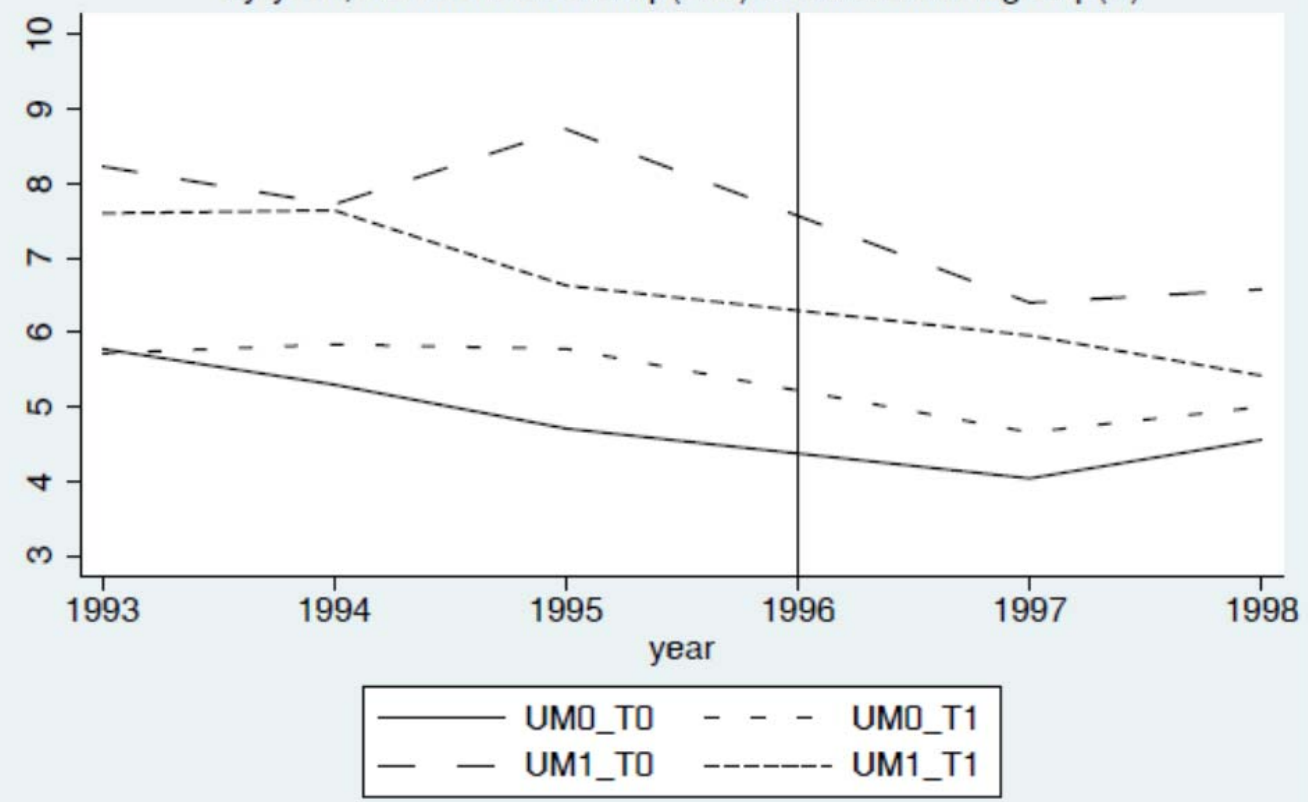

Source: SOEP: 1993-1999. 
Table 1: Sample Means by Treatment and Union Membership Status

\begin{tabular}{|c|c|c|c|c|}
\hline \multirow[b]{2}{*}{ Variable } & \multicolumn{2}{|c|}{ control group } & \multicolumn{2}{|c|}{ treatment group } \\
\hline & non-member & union member & non-member & union member \\
\hline No absence because of illness & 0.52 & 0.41 & 0.49 & 0.48 \\
\hline Days of sickness-related absence & 4.99 & 7.43 & 5.40 & 6.57 \\
\hline Disabled & 0.04 & 0.07 & 0.04 & 0.06 \\
\hline Age & 40.70 & 42.01 & 38.59 & 40.18 \\
\hline Tenure (in years) & 10.72 & 14.75 & 8.81 & 12.44 \\
\hline Male & 0.55 & 0.59 & 0.60 & 0.75 \\
\hline Firm size: $20 \leq X<200$ employees & 0.21 & 0.21 & 0.31 & 0.29 \\
\hline Firm size: $200 \leq X<2000$ employees & 0.22 & 0.23 & 0.20 & 0.28 \\
\hline Firm size: $X \geq 2000$ employees & 0.26 & 0.46 & 0.19 & 0.34 \\
\hline Blue collar worker & 0.08 & 0.17 & 0.34 & 0.58 \\
\hline Part-time worker & 0.15 & 0.11 & 0.15 & 0.06 \\
\hline Foreigner & 0.03 & 0.04 & 0.11 & 0.10 \\
\hline Children & 0.55 & 0.56 & 0.60 & 0.60 \\
\hline University degree & 0.32 & 0.27 & 0.16 & 0.10 \\
\hline Apprenticeship & 0.66 & 0.69 & 0.71 & 0.78 \\
\hline Partner & 0.08 & 0.07 & 0.10 & 0.07 \\
\hline Change of job since last year & 0.11 & 0.08 & 0.14 & 0.11 \\
\hline High job autonomy & 3.19 & 3.02 & 2.56 & 2.32 \\
\hline No sport activities & 0.31 & 0.33 & 0.35 & 0.41 \\
\hline Real gross wage last month (log) & 7.62 & 7.68 & 7.51 & 7.65 \\
\hline Immigrant & 0.05 & 0.06 & 0.13 & 0.12 \\
\hline Married & 0.62 & 0.69 & 0.62 & 0.68 \\
\hline Good health (subjective) & 0.62 & 0.58 & 0.63 & 0.59 \\
\hline Bad health (subjective) & 0.08 & 0.09 & 0.08 & 0.09 \\
\hline State unemployment rate & 11.82 & 12.63 & 11.61 & 12.17 \\
\hline Number of observations $(\mathrm{N})$ & 5615 & 2021 & 10715 & 3508 \\
\hline
\end{tabular}

Source: SOEP: 1993-1999. Survey weights are used.

The sample is an unbalanced panel of the survey years 1993, 1994, 1995, 1997, and 1998 including observations from workers who are eligible for sick pay or are self-employed, aged between 18 and 65 and work part-time or full-time. 
Table 2: Share of Employees with no Sickness-Related Absence

\begin{tabular}{|c|c|c|c|c|}
\hline & \multicolumn{2}{|c|}{ Overall effect } & \multicolumn{2}{|c|}{ Yearly effects } \\
\hline & $(1)$ & $(2)$ & $(1)$ & $(2)$ \\
\hline Year 1994 & $\begin{array}{l}-0.015 \\
(0.011)\end{array}$ & $\begin{array}{l}-0.025^{*} \\
(0.011)\end{array}$ & $\begin{array}{l}-0.015 \\
(0.011)\end{array}$ & $\begin{array}{l}-0.025^{*} \\
(0.011)\end{array}$ \\
\hline Year 1995 & $\begin{array}{c}-0.018 \\
(0.012)\end{array}$ & $\begin{array}{l}-0.032^{*} \\
(0.012)\end{array}$ & $\begin{array}{c}-0.018 \\
(0.012)\end{array}$ & $\begin{array}{l}-0.032^{*} \\
(0.012)\end{array}$ \\
\hline Year 1997 & $\begin{array}{c}0.017 \\
(0.012)\end{array}$ & $\begin{array}{c}0.015 \\
(0.012)\end{array}$ & $\begin{array}{l}0.022^{+} \\
(0.013)\end{array}$ & $\begin{array}{l}0.021^{+} \\
(0.013)\end{array}$ \\
\hline Post-reform (postreform) & $\begin{array}{l}-0.026 \\
(0.017)\end{array}$ & $\begin{array}{l}-0.052^{* *} \\
(0.018)\end{array}$ & $\begin{array}{l}-0.029^{+} \\
(0.017)\end{array}$ & $\begin{array}{l}-0.056^{* *} \\
(0.018)\end{array}$ \\
\hline Union membership (union) & $\begin{array}{l}-0.066^{* *} \\
(0.015)\end{array}$ & $\begin{array}{c}-0.040^{* *} \\
(0.015)\end{array}$ & $\begin{array}{l}-0.066^{* *} \\
(0.015)\end{array}$ & $\begin{array}{l}-0.040^{* *} \\
(0.015)\end{array}$ \\
\hline Treatment group (treatment) & $\begin{array}{l}-0.009 \\
(0.015)\end{array}$ & $\begin{array}{c}0.005 \\
(0.014)\end{array}$ & $\begin{array}{l}-0.009 \\
(0.015)\end{array}$ & $\begin{array}{c}0.005 \\
(0.014)\end{array}$ \\
\hline Post-reform $\times$ Treatment group & $\begin{array}{l}-0.007 \\
(0.019)\end{array}$ & $\begin{array}{l}-0.004 \\
(0.018)\end{array}$ & $\begin{array}{l}-0.007 \\
(0.019)\end{array}$ & $\begin{array}{l}-0.004 \\
(0.018)\end{array}$ \\
\hline Post-reform $\times$ Treatment group $\times$ Union & $\begin{array}{c}0.064^{*} \\
(0.026)\end{array}$ & $\begin{array}{c}0.062^{*} \\
(0.025)\end{array}$ & -- & -- \\
\hline Year $1997 \times$ Treatment group $\times$ Union & -- & -- & $\begin{array}{c}0.043 \\
(0.032)\end{array}$ & $\begin{array}{c}0.039 \\
(0.031)\end{array}$ \\
\hline Year $1998 \times$ Treatment group $\times$ Union & -- & -- & $\begin{array}{l}0.086^{* *} \\
(0.032)\end{array}$ & $\begin{array}{l}0.087^{* *} \\
(0.031)\end{array}$ \\
\hline Set of covariates & no & yes & no & yes \\
\hline Wald_X (df) & $25.36^{* *}(8)$ & $919.6^{* *}(44)$ & $26.28^{* *}(9)$ & $921.6^{* *}(45)$ \\
\hline $\mathrm{R}^{2}$ & 0.003 & 0.077 & 0.003 & 0.077 \\
\hline Number of observations (N) & & & & \\
\hline
\end{tabular}

Source: SOEP: 1993-1999. Linear Probability Model/ OLS-estimates. Survey weights are used.

Dependent variable: no absence because of illness (0/1).

Standard errors of the coefficients are robust to general second-moment misspecification.

Significance levels: ** (0.01), * (0.05), + (0.10).

Wald_X: Wald-test with $\mathrm{H}_{0}$ : no joint significance of all regressors. 
Table 3: Days of Sickness-Related Absence

\begin{tabular}{|c|c|c|c|c|}
\hline & \multicolumn{2}{|c|}{ Overall effect } & \multicolumn{2}{|c|}{ Yearly effects } \\
\hline & $(1)$ & $(2)$ & $(1)$ & $(2)$ \\
\hline Year 1994 & $\begin{array}{c}0.549^{*} \\
(0.238)\end{array}$ & $\begin{array}{l}0.660^{* *} \\
(0.245)\end{array}$ & $\begin{array}{c}0.549^{*} \\
(0.238)\end{array}$ & $\begin{array}{l}0.661^{* *} \\
(0.245)\end{array}$ \\
\hline Year 1995 & $\begin{array}{c}0.247 \\
(0.223)\end{array}$ & $\begin{array}{c}0.482^{*} \\
(0.228)\end{array}$ & $\begin{array}{c}0.247 \\
(0.223)\end{array}$ & $\begin{array}{c}0.483^{*} \\
(0.228)\end{array}$ \\
\hline Year 1997 & $\begin{array}{l}-0.322^{+} \\
(0.181)\end{array}$ & $\begin{array}{c}-0.308 \\
(0.190)\end{array}$ & $\begin{array}{l}-0.452^{*} \\
(0.188)\end{array}$ & $\begin{array}{l}-0.444^{*} \\
(0.195)\end{array}$ \\
\hline Post-reform (postreform) & $\begin{array}{l}-0.429 \\
(0.293)\end{array}$ & $\begin{array}{c}0.044 \\
(0.304)\end{array}$ & $\begin{array}{l}-0.363 \\
(0.294)\end{array}$ & $\begin{array}{c}0.115 \\
(0.307)\end{array}$ \\
\hline Union membership (union) & $\begin{array}{l}1.854^{* *} \\
(0.282)\end{array}$ & $\begin{array}{l}0.876^{* *} \\
(0.295)\end{array}$ & $\begin{array}{l}1.854^{* *} \\
(0.298)\end{array}$ & $\begin{array}{l}0.876^{* *} \\
(0.295)\end{array}$ \\
\hline Treatment group (treatment) & $\begin{array}{c}0.133 \\
(0.282)\end{array}$ & $\begin{array}{c}-0.631^{* *} \\
(0.271)\end{array}$ & $\begin{array}{c}0.133 \\
(0.282)\end{array}$ & $\begin{array}{l}-0.631^{*} \\
(0.271)\end{array}$ \\
\hline Post-reform $\times$ Treatment group & $\begin{array}{c}0.178 \\
(0.358)\end{array}$ & $\begin{array}{c}0.208 \\
(0.341)\end{array}$ & $\begin{array}{c}0.179 \\
(0.358)\end{array}$ & $\begin{array}{c}0.208 \\
(0.337)\end{array}$ \\
\hline Post-reform $\times$ Treatment group $\times$ Union & $\begin{array}{l}-1.065^{*} \\
(0.465)\end{array}$ & $\begin{array}{l}-1.053^{*} \\
(0.434)\end{array}$ & -- & -- \\
\hline Year $1997 \times$ Treatment group $\times$ Union & -- & -- & $\begin{array}{l}-0.586 \\
(0.581)\end{array}$ & $\begin{array}{l}-0.546 \\
(0.554)\end{array}$ \\
\hline Year $1998 \times$ Treatment group $\times$ Union & -- & -- & $\begin{array}{c}-1.575^{* *} \\
(0.536)\end{array}$ & $\begin{array}{c}-1.591^{* *} \\
(0.515)\end{array}$ \\
\hline Set of covariates & no & yes & no & yes \\
\hline Wald_X (df) & $81.6^{* *}(8)$ & $776.6^{* *}(44)$ & $83.88^{* *}(9)$ & $781.2^{* *}(45)$ \\
\hline $\mathrm{R}^{2}$ & 0.009 & 0.087 & 0.009 & 0.087 \\
\hline Number of observations $(\mathrm{N})$ & & & & \\
\hline
\end{tabular}

Source: SOEP: 1993-1999. OLS-estimates. Survey weights are used.

Dependent variable: days of sickness-related absence.

Standard errors of the coefficients are robust to general second-moment misspecification.

Significance levels: ** (0.01), * (0.05), + (0.10).

Wald_X: Wald-test with $\mathrm{H}_{0}$ : no joint significance of all regressors. 
Table 4: Distribution of Days of Sickness-Related Absence

\begin{tabular}{|c|c|c|c|c|c|c|c|c|c|c|}
\hline & \multicolumn{5}{|c|}{ Overall effect } & \multicolumn{5}{|c|}{ Yearly effects } \\
\hline & $\mathrm{q} \_0.5$ & q_0.6 & q_0.7 & $\mathrm{q} \_0.8$ & $\mathrm{q} \_0.9$ & q_0.5 & $\mathrm{q} \_0.6$ & $\mathrm{q} \_0.7$ & $\mathrm{q} \_0.8$ & q_ 0.9 \\
\hline Year 1994 & $\begin{array}{c}0.204^{+} \\
(0.110)\end{array}$ & $\begin{array}{c}0.224 \\
(0.201)\end{array}$ & $\begin{array}{c}0.275 \\
(0.248) \\
\end{array}$ & $\begin{array}{c}0.853^{*} \\
(0.379)\end{array}$ & $\begin{array}{c}1.014 \\
(0.676) \\
\end{array}$ & $\begin{array}{c}0.211^{+} \\
(0.111)\end{array}$ & $\begin{array}{c}0.235 \\
(0.204)\end{array}$ & $\begin{array}{c}0.296 \\
(0.251)\end{array}$ & $\begin{array}{c}0.839^{*} \\
(0.373)\end{array}$ & $\begin{array}{c}0.978 \\
(0.676) \\
\end{array}$ \\
\hline Year 1995 & $\begin{array}{c}0.315^{*} \\
(0.124)\end{array}$ & $\begin{array}{l}0.595^{* *} \\
(0.209)\end{array}$ & $\begin{array}{l}0.741^{* *} \\
(0.277)\end{array}$ & $\begin{array}{c}0.792^{*} \\
(0.391)\end{array}$ & $\begin{array}{c}0.876 \\
(0.609) \\
\end{array}$ & $\begin{array}{l}0.327^{* *} \\
(0.125)\end{array}$ & $\begin{array}{l}0.582^{* *} \\
(0.204)\end{array}$ & $\begin{array}{l}0.771^{\text {** }} \\
(0.281)\end{array}$ & $\begin{array}{c}0.785^{*} \\
(0.388)\end{array}$ & $\begin{array}{r}0.867 \\
(0.629) \\
\end{array}$ \\
\hline Year 1997 & $\begin{array}{c}-0.142 \\
(0.123)\end{array}$ & $\begin{array}{c}-0.106 \\
(0.188)\end{array}$ & $\begin{array}{c}-0.300 \\
(0.247)\end{array}$ & $\begin{array}{c}-0.142 \\
(0.345)\end{array}$ & $\begin{array}{c}-0.576 \\
(0.615)\end{array}$ & $\begin{array}{c}-0.179 \\
(0.132)\end{array}$ & $\begin{array}{c}-0.162 \\
(0.202)\end{array}$ & $\begin{array}{l}-0.413^{+} \\
(0.258)\end{array}$ & $\begin{array}{c}-0.301 \\
(0.339)\end{array}$ & $\begin{array}{l}-0.779 \\
(0.611)\end{array}$ \\
\hline Post-reform (postreform) & $\begin{array}{c}0.268 \\
(0.171)\end{array}$ & $\begin{array}{c}0.381 \\
(0.286)\end{array}$ & $\begin{array}{c}0.570 \\
(0.354)\end{array}$ & $\begin{array}{c}0.160 \\
(0.563)\end{array}$ & $\begin{array}{c}0.273 \\
(0.817)\end{array}$ & $\begin{array}{c}0.292^{+} \\
(0.174)\end{array}$ & $\begin{array}{c}0.418 \\
(0.287)\end{array}$ & $\begin{array}{c}0.682^{+} \\
(0.370)\end{array}$ & $\begin{array}{c}0.320 \\
(0.583)\end{array}$ & $\begin{array}{r}0.352 \\
(0.830)\end{array}$ \\
\hline Union membership (union) & $\begin{array}{l}0.747^{* *} \\
(0.284)\end{array}$ & $\begin{array}{l}1.155^{* *} \\
(0.364)\end{array}$ & $\begin{array}{l}1.571^{* *} \\
(0.428)\end{array}$ & $\begin{array}{l}2.074^{* *} \\
(0.468)\end{array}$ & $\begin{array}{c}1.734^{*} \\
(0.749)\end{array}$ & $\begin{array}{l}0.749^{* * *} \\
(0.285)\end{array}$ & $\begin{array}{l}1.173^{* *} \\
(0.365)\end{array}$ & $\begin{array}{l}1.565^{* *} \\
(0.426)\end{array}$ & $\begin{array}{l}2.071^{* *} \\
(0.470)\end{array}$ & $\begin{array}{c}1.623^{*} \\
(0.752)\end{array}$ \\
\hline Treatment group (treatment) & $\begin{array}{l}-0.377^{*} \\
(0.163)\end{array}$ & $\begin{array}{l}-0.580^{*} \\
(0.260)\end{array}$ & $\begin{array}{c}-0.544 \\
(0.338)\end{array}$ & $\begin{array}{c}-0.814 \\
(0.544)\end{array}$ & $\begin{array}{l}-0.028 \\
(0.761)\end{array}$ & $\begin{array}{l}-0.382^{*} \\
(0.162)\end{array}$ & $\begin{array}{l}-0.558^{*} \\
(0.260)\end{array}$ & $\begin{array}{l}-0.575^{+} \\
(0.334)\end{array}$ & $\begin{array}{l}-0.810 \\
(0.551)\end{array}$ & $\begin{array}{l}-0.044 \\
(0.755) \\
\end{array}$ \\
\hline Post-reform $\times$ Treatment group & $\begin{array}{c}0.016 \\
(0.172) \\
\end{array}$ & $\begin{array}{l}-0.095 \\
(0.276)\end{array}$ & $\begin{array}{c}-0.166 \\
(0.356)\end{array}$ & $\begin{array}{c}0.208 \\
(0.589)\end{array}$ & $\begin{array}{l}-0.426 \\
(0.941) \\
\end{array}$ & $\begin{array}{c}0.025 \\
(0.172) \\
\end{array}$ & $\begin{array}{c}-0.116 \\
(0.273)\end{array}$ & $\begin{array}{l}-0.173 \\
(0.355) \\
\end{array}$ & $\begin{array}{c}0.175 \\
(0.592) \\
\end{array}$ & $\begin{array}{l}-0.364 \\
(0.939 \\
\end{array}$ \\
\hline $\begin{array}{l}\text { Post-reform } \times \text { Treatment group } \times \\
\text { Union }\end{array}$ & $\begin{array}{l}-0.834^{*} \\
(0.355) \\
\end{array}$ & $\begin{array}{l}-1.190^{*} \\
(0.520)\end{array}$ & $\begin{array}{l}-1.572^{* *} \\
(0.605) \\
\end{array}$ & $\begin{array}{l}-2.489^{* *} \\
(0.876) \\
\end{array}$ & $\begin{array}{l}-1.793 \\
(1.106) \\
\end{array}$ & -- & -- & -- & -- & -- \\
\hline Year $1997 \times$ Treatment group $\times$ Union & -- & -- & -- & -- & -- & $\begin{array}{l}-0.775 \\
(0.466) \\
\end{array}$ & $\begin{array}{l}-1.099 \\
(0.726) \\
\end{array}$ & $\begin{array}{l}-0.936 \\
(0.777) \\
\end{array}$ & $\begin{array}{l}-1.464 \\
(1.201)\end{array}$ & $\begin{array}{l}-0.240 \\
(1.448 \\
\end{array}$ \\
\hline Year $1998 \times$ Treatment group $\times$ Union & -- & -- & -- & -- & -- & $\begin{array}{l}-0.995^{*} \\
(0.404)\end{array}$ & $\begin{array}{l}-1.304^{*} \\
(0.637)\end{array}$ & $\begin{array}{l}-2.102^{* *} \\
(0.682)\end{array}$ & $\begin{array}{c}-3.675^{* *} \\
(0.916)\end{array}$ & $\begin{array}{l}-2.475 \\
(1.454) \\
\end{array}$ \\
\hline Set of covariates & yes & yes & yes & yes & yes & yes & yes & yes & yes & yes \\
\hline Number of observations (N) & & & & & & & & & & \\
\hline
\end{tabular}

Source: SOEP: 1993-1999. Quantile regression estimates. Survey weights are used.

Dependent variable: q $0.5-\mathrm{q}$ 0.9: $\tau$-th quantile of distribution of days of sickness-related absence.

Standard errors come from a nonparametric panel-bootstrap procedure with 200 replications.

Significance levels: ** $(0.01), *(0.05),+(0.10)$.

Wald_X: Wald-test with $\mathrm{H}_{0}$ : no joint significance of all regressors. 
Table 5: Robustness Checks

\begin{tabular}{|c|c|c|c|c|c|c|c|c|c|c|c|c|c|c|}
\hline & \multirow{2}{*}{\multicolumn{2}{|c|}{ Job stayer }} & \multirow{2}{*}{\multicolumn{2}{|c|}{$\begin{array}{c}\text { No change in } \\
\text { union status }\end{array}$}} & \multirow{2}{*}{\multicolumn{2}{|c|}{$\begin{array}{c}\text { PADA } \\
\text { applicable }\end{array}$}} & \multicolumn{2}{|c|}{$\begin{array}{c}\text { Firm size } \\
\text { greater than } \\
200\end{array}$} & \multicolumn{2}{|c|}{$\begin{array}{c}\text { Including long- } \\
\text { term sickness } \\
\text { spells }\end{array}$} & \multicolumn{2}{|c|}{$\begin{array}{l}\text { Including } \\
\text { "Union × } \\
\text { Treatment } \\
\text { group" }\end{array}$} & \multicolumn{2}{|c|}{$\begin{array}{l}\text { Propensity } \\
\text { score } \\
\text { reweighting }\end{array}$} \\
\hline & & & & & & & & & 5 & & & & & \\
\hline & No abs. & Days & No abs. & Days & No abs. & Days & No abs. & Days & No abs. & Days & No abs. & Days & No abs. & Days \\
\hline $\begin{array}{l}\text { Year } 1997 \times \\
\text { Treatment group } \times \\
\text { Union }\end{array}$ & $\begin{array}{l}0.065^{+} \\
(0.038)\end{array}$ & $\begin{array}{l}-0.631 \\
(0.681)\end{array}$ & $\begin{array}{c}0.026 \\
(0.036)\end{array}$ & $\begin{array}{c}0.131 \\
(0.661)\end{array}$ & $\begin{array}{c}0.016 \\
(0.034)\end{array}$ & $\begin{array}{l}-0.283 \\
(0.609)\end{array}$ & $\begin{array}{l}-0.021 \\
(0.042)\end{array}$ & $\begin{array}{c}0.311 \\
(0.813)\end{array}$ & $\begin{array}{c}0.046 \\
(0.030)\end{array}$ & $\begin{array}{l}-1.076 \\
(0.815)\end{array}$ & $\begin{array}{l}-0.002 \\
(0.033)\end{array}$ & $\begin{array}{l}-0.030 \\
(0.594)\end{array}$ & $\begin{array}{c}0.026 \\
(0.037)\end{array}$ & $\begin{array}{c}0.013 \\
(0.688)\end{array}$ \\
\hline $\begin{array}{l}\text { Year } 1998 \times \\
\text { Treatment group } \times \\
\text { Union }\end{array}$ & $\begin{array}{l}0.083^{*} \\
(0.037)\end{array}$ & $\begin{array}{l}-1.777^{* *} \\
(0.655)\end{array}$ & $\begin{array}{l}0.064^{+} \\
(0.039)\end{array}$ & $\begin{array}{l}-1.159^{+} \\
(0.592)\end{array}$ & $\begin{array}{l}0.072^{*} \\
(0.033)\end{array}$ & $\begin{array}{l}-1.608^{* *} \\
(0.559)\end{array}$ & $\begin{array}{l}0.096^{*} \\
(0.040)\end{array}$ & $\begin{array}{l}-1.642^{*} \\
(0.699)\end{array}$ & $\begin{array}{l}0.082^{* *} \\
(0.028)\end{array}$ & $\begin{array}{l}-2.097^{*} \\
(0.913)\end{array}$ & $\begin{array}{c}0.045 \\
(0.032)\end{array}$ & $\begin{array}{l}-1.076^{+} \\
(0.558)\end{array}$ & $\begin{array}{l}0.082^{*} \\
(0.036)\end{array}$ & $\begin{array}{l}-1.207^{+} \\
(0.642)\end{array}$ \\
\hline Set of covariates & yes & yes & yes & yes & yes & yes & yes & yes & yes & yes & yes & yes & yes & yes \\
\hline $\begin{array}{l}\text { Number of } \\
\text { observations }(\mathrm{N})\end{array}$ & \multicolumn{2}{|c|}{16694} & \multicolumn{2}{|c|}{16792} & \multicolumn{2}{|c|}{16053} & \multicolumn{2}{|c|}{10101} & \multicolumn{2}{|c|}{23421} & \multicolumn{2}{|c|}{21859} & \multicolumn{2}{|c|}{21745} \\
\hline
\end{tabular}

Source: SOEP: 1993-1999. Linear Probability Model; OLS. Survey weights are used.

Dependent variables: "No abs.": no absence because of illness (0/1); "Days": days of sickness-related absence.

Standard errors of the coefficients are robust to general second-moment misspecification. Significance levels: ** $(0.01), *(0.05),+(0.10)$

See Section 6.4 for details. 
Appendix:

\section{Table A1: Descriptive Statistics}

\begin{tabular}{|c|c|c|}
\hline Variable & Mean & S.E. \\
\hline Share of non-absent employees & 0.49 & 0.50 \\
\hline Days of sickness-related absence & 5.66 & 9.46 \\
\hline Union membership & 0.24 & 0.43 \\
\hline Disabled & 0.05 & 0.21 \\
\hline Age & 39.74 & 10.83 \\
\hline Tenure (in years) & 10.44 & 9.72 \\
\hline Male & 0.61 & 0.49 \\
\hline Firm size: $20 \leq X<200$ employees & 0.27 & 0.44 \\
\hline Firm size: $200 \leq X<2000$ employees & 0.22 & 0.414 \\
\hline Firm size: $X \geq 2000$ employees & 0.26 & 0.44 \\
\hline Blue collar worker & 0.29 & 0.45 \\
\hline Part-time worker & 0.13 & 0.34 \\
\hline Foreigner & 0.08 & 0.27 \\
\hline Children in the household (1 if yes) & 0.58 & 0.49 \\
\hline University degree & 0.21 & 0.40 \\
\hline Apprenticeship & 0.70 & 0.46 \\
\hline Partner & 0.09 & 0.28 \\
\hline Change of job since last year & 0.12 & 0.33 \\
\hline High job autonomy (values $0-5$ ) & 2.74 & 1.17 \\
\hline No sports activities (1 if no exercise) & 0.35 & 0.48 \\
\hline Real gross wage last month $(\log )$ & 7.58 & 0.61 \\
\hline Immigrant & 0.10 & 0.230 \\
\hline Married & 0.63 & 0.48 \\
\hline Good health (best 2 of 5 categories) & 0.61 & 0.49 \\
\hline Bad health (worst 2 of 5 categories) & 0.08 & 0.28 \\
\hline State unemployment rate & 11.85 & 3.70 \\
\hline Year 1993 & 0.19 & 0.39 \\
\hline Year 1994 & 0.21 & 0.41 \\
\hline Year 1995 & 0.19 & 0.39 \\
\hline Year 1997 & 0.21 & 0.41 \\
\hline Year 1998 & 0.20 & 0.40 \\
\hline Number of observations (N) & \multicolumn{2}{|c|}{21859} \\
\hline
\end{tabular}

Source: SOEP 1993-1999. Survey weights are used.

The sample is an unbalanced panel of the survey years 1993, 1994, 1995, 1997, and 1998 including observations from workers who are eligible for sick pay or are self-employed, aged between 18 and 65 and work part-time or full-time. The variable "job autonomy" refers to an average value stemming from an interval ranging from 0 (apprentice) to 5 (high autonomy). Dummies for federal states are not documented. 
Table A2: Share of Employees with no Sickness-Related Absence (complete estimates)

\begin{tabular}{|c|c|c|c|c|}
\hline & \multicolumn{2}{|c|}{ Overall effect } & \multicolumn{2}{|c|}{ Yearly effects } \\
\hline & Coef. & $S E$ & Coef. & $S E$ \\
\hline Constant & $0.413^{* *}$ & 0.107 & $0.412^{* *}$ & 0.107 \\
\hline Disabled & $-0.070^{* *}$ & 0.025 & $-0.070^{* *}$ & 0.025 \\
\hline Age & $0.016^{* *}$ & 0.004 & $0.016^{* *}$ & 0.004 \\
\hline Age squared & $-0.000^{*}$ & 0.000 & $-0.000^{*}$ & 0.000 \\
\hline Tenure (in years) & -0.000 & 0.001 & -0.000 & 0.001 \\
\hline Male & $0.129^{* *}$ & 0.014 & $0.129^{* *}$ & 0.014 \\
\hline Firm size: $20 \leq X<200$ employees & $-0.113^{* *}$ & 0.015 & $-0.113^{* *}$ & 0.015 \\
\hline Firm size: $200 \leq X<2000$ employees & $-0.149^{* *}$ & 0.016 & $-0.149^{* *}$ & 0.016 \\
\hline Firm size: $X \geq 2000$ employees & $-0.167^{* *}$ & 0.016 & $-0.167^{* *}$ & 0.016 \\
\hline Blue collar worker & -0.023 & 0.015 & -0.023 & 0.015 \\
\hline Part-time worker & 0.005 & 0.019 & 0.005 & 0.019 \\
\hline Foreigner & -0.012 & 0.027 & -0.013 & 0.027 \\
\hline Children & $0.041^{* *}$ & 0.013 & $0.041^{* *}$ & 0.013 \\
\hline University degree & -0.003 & 0.018 & -0.003 & 0.018 \\
\hline Apprenticeship & $0.023^{+}$ & 0.014 & $0.023^{+}$ & 0.014 \\
\hline Partner & $-0.051^{*}$ & 0.020 & $-0.051^{*}$ & 0.020 \\
\hline New job & $0.023^{+}$ & 0.014 & $0.023^{+}$ & 0.014 \\
\hline Job autonomy (values $0-5$ ) & $0.026^{* *}$ & 0.007 & $0.026^{* *}$ & 0.007 \\
\hline No sports & 0.013 & 0.011 & 0.013 & 0.011 \\
\hline Real monthly gross wage (log) & $-0.060^{* *}$ & 0.013 & $-0.060^{* *}$ & 0.013 \\
\hline Immigrant & 0.034 & 0.025 & 0.034 & 0.025 \\
\hline Married & $-0.041^{* *}$ & 0.015 & $-0.041^{* *}$ & 0.015 \\
\hline Health good & $0.090^{* *}$ & 0.011 & $0.090^{* *}$ & 0.011 \\
\hline Health bad & $-0.110^{* *}$ & 0.018 & $-0.110^{* *}$ & 0.018 \\
\hline Year 1994 & $-0.025^{*}$ & 0.011 & $-0.025^{*}$ & 0.011 \\
\hline Year 1995 & $-0.032^{*}$ & 0.012 & $-0.032^{*}$ & 0.012 \\
\hline Year 1997 & 0.015 & 0.012 & $0.021^{+}$ & 0.013 \\
\hline Unemployment rate (state level) & $0.006^{+}$ & 0.003 & $0.006^{+}$ & 0.003 \\
\hline Post-reform (postreform) & $-0.052^{* *}$ & 0.018 & $-0.056^{* *}$ & 0.018 \\
\hline Union membership (union) & $-0.040^{* *}$ & 0.015 & $-0.040^{* *}$ & 0.015 \\
\hline Treatment group (treatment) & 0.005 & 0.014 & 0.005 & 0.014 \\
\hline Post-reform $\times$ Treatment group & -0.004 & 0.018 & -0.004 & 0.018 \\
\hline Post-reform $\times$ Treatment group $\times$ Union & $0.062^{*}$ & 0.025 & -- & -- \\
\hline Year $1997 \times$ Treatment group $\times$ Union & -- & -- & 0.039 & 0.031 \\
\hline Year $1998 \times$ Treatment group $\times$ Union & -- & -- & $0.087^{* *}$ & 0.031 \\
\hline Wald_X (df) & \multicolumn{2}{|c|}{$919.6^{* *}(44)$} & \multicolumn{2}{|c|}{$921.6^{* *}(45)$} \\
\hline $\mathrm{R}^{2}$ & \multicolumn{2}{|c|}{0.077} & \multicolumn{2}{|c|}{0.077} \\
\hline Number of observations (N) & \multicolumn{4}{|c|}{21859} \\
\hline
\end{tabular}

Source: SOEP: 1993-1999. Linear Probability Model/ OLS-estimates. Survey weights are used.

Dependent variable: no absence because of illness (0/1).

Standard errors (SE) of the coefficients are robust to general second-moment misspecification.

Significance levels: ** $(0.01), *(0.05),+(0.10)$.

Wald_X: Wald-test with $\mathrm{H}_{0}$ : no joint significance of all regressors.

Parameter estimates for federal state dummies are not documented. 
Table A3: Days of Sickness-Related Absence (complete estimates)

\begin{tabular}{|c|c|c|c|c|}
\hline & \multicolumn{2}{|c|}{ Overall effect } & \multicolumn{2}{|c|}{ Yearly effects } \\
\hline & Coef. & $S E$ & Coef. & $S E$ \\
\hline Constant & $7.551^{* *}$ & 1.717 & $7.563^{* *}$ & 1.716 \\
\hline Disabled & $2.699^{* *}$ & 0.668 & $2.699^{* *}$ & 0.668 \\
\hline Age & $-0.287^{* *}$ & 0.085 & $-0.286^{* *}$ & 0.085 \\
\hline Age squared & $0.003^{* *}$ & 0.001 & $0.003^{* *}$ & 0.001 \\
\hline Tenure (in years) & -0.001 & 0.015 & -0.001 & 0.015 \\
\hline Male & $-2.035^{* *}$ & 0.228 & $-2.032^{* *}$ & 0.228 \\
\hline Firm size: $20 \leq X<200$ employees & $1.193^{* *}$ & 0.231 & $1.196^{* *}$ & 0.231 \\
\hline Firm size: $200 \leq X<2000$ employees & $1.813^{* *}$ & 0.262 & $1.816^{* *}$ & 0.262 \\
\hline Firm size: $X \geq 2000$ employees & $2.485^{* *}$ & 0.270 & $2.486^{* *}$ & 0.270 \\
\hline Blue collar worker & $1.276^{* *}$ & 0.278 & $1.272^{* *}$ & 0.278 \\
\hline Part-time worker & -0.410 & 0.361 & -0.411 & 0.361 \\
\hline Foreigner & 0.261 & 0.444 & 0.268 & 0.444 \\
\hline Children & -0.217 & 0.224 & -0.220 & 0.224 \\
\hline University degree & $-0.702^{*}$ & 0.287 & $-0.701^{*}$ & 0.287 \\
\hline Apprenticeship & -0.208 & 0.253 & -0.206 & 0.253 \\
\hline Partner & 0.499 & 0.311 & 0.496 & 0.311 \\
\hline New job & -0.340 & 0.226 & -0.343 & 0.226 \\
\hline Job autonomy (values 0-5) & $-0.874^{* *}$ & 0.118 & $-0.874^{* *}$ & 0.118 \\
\hline No sports & 0.066 & 0.211 & 0.066 & 0.211 \\
\hline Real monthly gross wage $(\log )$ & $0.913^{* *}$ & 0.237 & $0.911^{* *}$ & 0.237 \\
\hline Immigrant & -0.231 & 0.419 & -0.230 & 0.419 \\
\hline Married & 0.445 & 0.280 & 0.444 & 0.280 \\
\hline Health good & $-1.853^{* *}$ & 0.203 & $-1.856^{* *}$ & 0.203 \\
\hline Health bad & $3.602^{* *}$ & 0.467 & $3.599^{* *}$ & 0.467 \\
\hline Year 1994 & $0.660^{* *}$ & 0.245 & $0.661^{* *}$ & 0.245 \\
\hline Year 1995 & $0.482^{*}$ & 0.228 & $0.483^{*}$ & 0.228 \\
\hline Year 1997 & -0.308 & 0.190 & $-0.444^{*}$ & 0.195 \\
\hline Unemployment rate (state level) & $-0.088^{+}$ & 0.051 & $-0.089^{+}$ & 0.051 \\
\hline Post-reform (postreform) & 0.044 & 0.304 & 0.115 & 0.307 \\
\hline Union membership (union) & $0.876^{* *}$ & 0.295 & $0.876^{* *}$ & 0.295 \\
\hline Treatment group (treatment) & $-0.631^{*}$ & 0.271 & $-0.631^{*}$ & 0.271 \\
\hline Post-reform $\times$ Treatment group & 0.208 & 0.341 & 0.208 & 0.341 \\
\hline Post-reform $\times$ Treatment group $\times$ Union & $-1.053^{*}$ & 0.434 & -- & -- \\
\hline Year $1997 \times$ Treatment group $\times$ Union & -- & -- & -0.546 & 0.554 \\
\hline Year $1998 \times$ Treatment group $\times$ Union & -- & -- & $-1.591^{* *}$ & 0.515 \\
\hline Wald_X (df) & \multicolumn{2}{|c|}{$766.6^{* *}(44)$} & \multicolumn{2}{|c|}{$781.2^{* *}(45)$} \\
\hline $\mathrm{R}^{2}$ & \multicolumn{2}{|c|}{0.087} & \multirow{2}{*}{\multicolumn{2}{|c|}{0.087}} \\
\hline Number of observations (N) & & & & \\
\hline
\end{tabular}

Source: SOEP: 1993-1999. OLS-estimates. Survey weights are used.

Dependent variable: days of sickness-related absence.

Standard errors (SE) of the coefficients are robust to general second-moment misspecification.

Significance levels: ** $(0.01), *(0.05),+(0.10)$.

Wald_X: Wald-test with $\mathrm{H}_{0}$ : no joint significance of all regressors.

Parameter estimates for federal state dummies are not documented. 


\section{References}

Allen, Steven G. (1981), An Empirical Model of Work Attendance, The Review of Economics and Statistics 63(1), 77-87.

Allen, Steven G. (1984), Trade Unions, Absenteeism, and Exit-Voice, Industrial and Labor Relations Review 37(3), 331-345.

Andersen, Signe Hald (2010), The Cost of Sickness: On the Effect of the Duration of Sick Leave on Post-Sick Leave Earnings, Social Science \& Medicine 70(10), 1581-1589.

BAG (Bundesarbeitsgericht/ Federal Labour Court) (2000), 5 AZR 117/99, (http://lexetius.com/2000,4556, accessed May 7, 2012).

Bauer, Jobst-Hubertus and Stefan Lingemann (1996), Probleme der Entgeltfortzahlung nach neuem Recht, BetriebsBerater 17, 8-18.

Berger, Helge and Michael Neugart (2012), How German Labour Courts Decide - an Econometric Case Study, German Economic Review 13(1), 56-70.

Böckerman, Petri and Pekka Ilmakunnas (2008), Interaction of Working Conditions, Job Satisfaction, and Sickness Absences: Evidence from a Representative Sample of Employees, Social Science and Medicine 67(4), 520-528.

Brown, Sarah and John G. Sessions (1996), The Economics of Absence: Theory and Evidence, Journal of Economic Surveys 10(1), 23-53.

Budd, John W. and In-Gang Na (2000), The Union Membership Wage Premium for Employees Covered by Collective Bargaining Agreements, Journal of Labor Economics 18(4), 783-807.

Busso, Matias, DiNardo, John and Justin McCrary (2011), New Evidence on the Finite Sample Properties of Propensity Score Reweighting and Matching Estimators, (http://emlab.berkeley.edu/ jmccrary/BDM2011.pdf, accessed May 7, 2012).

Chaudhury, Mohammed and Ignace Ng (1992), Absenteeism Predictors, Least Squares, Rank Regression, and Model Selection Results, The Canadian Journal of Economics 25(3), 615-635.

Dionne, Georges and Benoit Dostie (2007), New Evidence on the Determinants of Absenteeism using Linked Employer-Employee Data, Industrial and Labor Relations Review 61(1), 108-120.

Ellguth, Peter (2003), Quantitative Reichweite der betrieblichen Mitbestimmung, WSI Mitteilungen 3, 194-199.

Engström, Per and Bertil Homlund (2007), Worker Absenteeism in Search Equilibrium, Scandinavian Journal of Economics 109(3), 439-467.

Eren, Ozkan (2009), Does Membership Pay Off for Covered Workers? A Distributional Analysis of the Free Rider Problem, Industrial and Labor Relations Review 62(3), 367-380.

Fitzenberger, Bernd, Ernst, Michaela and Isabell Haggeney (1999), Wer ist noch Mitglied in Gewerkschaften?, Zeitschrift für Wirtschafts- und Sozialwissenschaften 119(2), 223-263.

Freeman, Richard (1980), The Exit-Voice Tradeoff in the Labor Market: Unionism, Job Tenure, Quits, and Separations, The Quarterly Journal of Economics 94(4), 643-673.

García-Serrano, Carlo and Miguel A. Malo (2009), The Impact of Union Direct Voice on Voluntary and Involuntary Absenteeism, The Journal of Socio-Economics 38(2), 372-383.

Goerke, Laszlo and Markus Pannenberg (2004), Norm-Based Trade Union Membership: Evidence for Germany, German Economic Review 5(4), 481-504.

Goerke, Laszlo and Markus Pannenberg (2010), An Economic Analysis of Dismissal Legislation: Determinants of Severance Pay in West Germany, International Review of Law and Economics 30(1), 71-85. 
Goerke, Laszlo and Markus Pannenberg (2011), Trade Union Membership and Dismissals, Labour Economics 18(6), 810-821.

Haisken-DeNew, John P. and Markus H. Hahn (2010), PanelWhiz: Efficient Data Extraction of Complex Panel Data Sets - An Example Using the German SOEP, Journal of Applied Social Science Studies 130(4), 643-654.

Hastings, Justine S. and Jeffrey M. Weinstein (2008), Information, School Choice, and Academic Achievement: Evidence from Two Experiments, Quarterly Journal of Economics 123(4), 1373-1414.

Hansen, Jörg (2000), The Effect of Work Absence on Wages and Wage Gaps in Sweden, Journal of Population Economics 13(1), 45-55.

Hassink, Wolter H.J. and Pierre W.C. Koning (2009), Do Financial Bonuses Reduce Employee Absenteeism? Evidence from a Lottery, Industrial and Labor Relations Review 62(3), 327-342.

Henningsen, Morten and Torbjørn Hægeland (2008), Downsizing as a Sorting Device - Are Low-productive Workers more likely to Leave Downsizing Firms? Discussion Papers No. 543, Statistics Norway.

Hesselius, Patrik (2007), Does Sickness Absence Increase the Risk of Unemployment? The Journal of Socio-Economics 36(2), 288-310.

Hesselius, Patrik, Johansson, Per and J. Peter Nilsson (2009), Sick of Your Colleagues' Absence?, Journal of the European Economic Association 7(2-3), 583-594.

Hildreth, Andrew K. G. (2000), Union Wage Differentials for Covered Members and Nonmembers in Great Britain, Journal of Labor Research 21(1), 133-147.

Ichino, Andrea and Regina T. Riphahn (2005), The Effect of Employment Protection on Worker Effort: Absenteeism During and After Probation, Journal of the European Economic Association 3(1), 120-143.

Imbens, Guido W. and Jeffrey M. Wooldridge (2009), Recent Developments in the Econometrics of Program Evaluation, Journal of Economic Literature 47(1), 5-86.

Johansson, Per and Marten Palme (2005), Moral Hazard and Sickness Insurance, Journal of Public Economics 89(9-10), 879-1890.

Knight, K. G. and Paul L. Latreille (2000), Discipline, Dismissals and Complaints to Employment Tribunals, British Journal of Industrial Relations 38(4), 533-555.

Kohaut, Susanne and Claus Schnabel (2003), Zur Erosion des Flächentarifvertrags: Ausmaß, Einflussfaktoren und Gegenmaßnahmen, Industrielle Beziehungen 10(2), 193-219.

Leigh, J. Paul (1981), The Effects of Union Membership on Absence from Work Due to Illness, Journal of Labor Research 2(2), 329-336.

Leigh, J. Paul (1984), Unionization and Absenteeism, Applied Economics 16(1), 147-157.

Leigh, J. Paul (1985), The Effects of Unemployment and the Business Cycle on Absenteeism, Journal of Economics and Business 37(2), 159-170.

Leigh, J. Paul (1991), Employee and Job Attributes as Predictors of Absenteeism in a National Sample of Workers: The Importance of Health and Dangerous Working Conditions, Social Science and Medicine 33(2), 127-137.

Lusinyan, Lusine and Leo Bonato (2007), Work Absence in Europe, IMF Staff Papers 54(3), 475-538.

Machado, José A.F. and J. M. C. Santos Silva (2005), Quantiles for Counts, Journal of the American Statistical Association 100(427), 1226-1237.

Mastekaasa, Arne (2011), Unionization and Sickness Absence (http://www.sv.uio.no/ iss/om/aktuelt/arrangementer/aks/2011/Mastekaasa.pdf, accessed August 08, 2011). 
Markussen, Simen (2012), The Individual Cost of Sick Leave, Journal of Population Economics, 25(4), 1287-1306.

Moffitt, Robert (1983), An Economic Model of Welfare Stigma, American Economic Review 73(5), 1023-1035.

Moreton, David R. (1998), An Open Trade Union Model of Wages, Effort and Membership, European Journal of Political Economy 14(3), 511-527.

Moreton, David R. (1999), A Model of Labour Productivity and Union Density in British Private Sector Unionised Establishments, Oxford Economic Papers 51(2), 322-344.

OECD (2004), Employment Outlook, Chapter 2: Employment Protection Regulation and Labour Market Performance, 61-125, Paris.

Olsson, Martin (2009), Employment Protection and Sickness Absence, Labour Economics $16(2), 208-214$.

Pfarr, Heide, Ullmann, Karen, Bradtke, Marcus, Schneider, Julia, Kimmich, Martin and Silke Bothfeld (2005), Der Kündigungsschutz zwischen Wahrnehmung und Wirklichkeit, Rainer Hampp Verlag.

Puhani, Patrick A. and Katja Sonderhof (2010), The Effects of a Sick Pay Reform on Absence and on Health-Related Outcomes, Journal of Health Economics 29(2), 285-302.

Schmidt, Christoph and Klaus F. Zimmermann (1991), Work Characteristics, Firm Size and Wages, The Review of Economics and Statistics 73(4), 705-710.

Schnabel, Claus and Joachim Wagner (2007), The Persistent Decline in Unionization in Western and Eastern Germany, 1980-2004: What Can We Learn from a Decomposition Analysis?, Industrielle Beziehungen 14(2), 118-132.

Schumacher, Edward J. (1999), What Explains Wage Differences Between Union Members and Covered Nonmembers?, Southern Economic Journal 65(3), 493-512.

Veliziotis, Michail (2010), Unionization and Sickness Absence from Work in the UK, Institute for Social \& Economic Research, DP No. 2010-15.

Visser, Jelle (2011), The ICTWSS Database, Amsterdam (http://www.uva-aias.net/208, accessed July 11, 2011).

Vistnes, Jessica P. (1997), Gender Differences in Days Lost From Work due to Illness, Industrial and Labor Relations Review 50(2), 304-321.

Wagner, Gerd G., Frick, Joachim R. and Jürgen Schupp (2007), The German Socio-Economic Panel Study (SOEP) - Scope, Evolution, and Enhancements, Schmollers Jahrbuch 127(1), 139-169.

Wagner, Joachim (1991), Gewerkschaftsmitgliedschaft und Arbeitseinkommen in der Bundesrepublik Deutschland, Ifo-Studien 37(2), 109-140.

Wooldridge, Jeffrey (2011), Difference-in-Differences Estimation, Lecture "Topics in Microeconometrics", (http://www.eief.it/files/2011/10/slides_6_diffindiffs.pdf, accessed May 11, 2012)

Ziebarth, Nicolas R. and Martin Karlsson (2010), A Natural Experiment on Sick Pay Cuts, Sickness Absence, and Labor Costs, Journal of Public Economics 94(11-12), 1108-1122.

Ziebarth, Nicolas R. (2012), Long-Term Absenteeism and Moral Hazard - Evidence from a Natural Experiment, (http://www.human.cornell.edu/pam/people/upload/Long-termabsenteeism-and-moral-hazard_Evidence-from-a-natural-experiment_revised.pdf, accessed May 7, 2012). 